\title{
Beyazperdeden Dijital Medyaya: Film İzleme Deneyiminin Değişimi Üzerine Bir Araştırma
}

\author{
DOI: 10.26466/opus.796968
}

*

\author{
Batu Anadolu * \\ * Arş. Gör. Dr., Çukurova Üniversitesi, İletişim Fakültesi, Adana/Türkiye \\ E-Posta: banadolu@live.com \\ ORCID: $\underline{0000-0002-7420-3818}$
}

\section{Öz}

Bu çalışma ile yeni iletişim ortamlarının yarattı̆̆ imkanlar doğrultusunda, sinema deneyiminde ve gösterim olanaklarında yaşanan değişim incelenmiştir. Sinemanın bir endüstriye dönüşmesinde gösterim pratiklerinin rolü ve gelişimi önem arz etmektedir. İnsanlarn sinema salonlarna gitmesinde boş zamanı değerlendirme, kamusal alana çıkma ve sosyalleşme gibi unsurlar rol oynarken, zaman içerisinde film gösterim mekanları ve film izleme deneyimleri çoğullaşmıştır. Bu gelişmeler, bir filmin deneyimlenmesindeki tercih ve davranışlar üzerine yeniden düşünmeyi gerektirmektedir. Çalışmanın amacı; bahsi geçen değişim aracılı̆̆ıla izleyicilerin sinema salonunun içinde ya da dışında film izlemesine neden olan faktörleri ve motivasyonları tanımlamak, geleceğe dönük bir perspektif oluşturarak alana katkı sağlamaktır. Çalışma kapsamında İstanbul'da bulunan altı üniversitenin sinema kulüplerindeki gösterimlere katılan kırk sekiz öğrenciyle derinlemesine görüşmeler gerçekleştirilmiş ve elde edilen bulgular betimsel analize tabi tutulmuştur. Çalışmada yer verilen sinema kulüplerinin film izleme deneyiminin sürdü̆̈̈̈, film materyallerinin ve dijital medya platformlarının paylaşıldığı yerler olduğu tespit edilmiş, ayrıca katılımcılarda ticari salonlarda da düzenli film izleme şartı aranmıştır. Bulguların yorumlanmasıyla şu sonuçlara ulaşılmıştır: Katılımcılar için sinemaya gitmek her şeyden önce sosyal bir aktivitedir. Katıllmcilar; bilişsel, içeriksel ve duygusal-bütünleştirici faktörlere yönelik olumlu bir yaklaşım oluşturmaktadırlar. Bunun yanında mekana bağlı faktörler, dijitalleşmeye bir tepki olarak ön plana çıkmaktadır. Sinema salonu dışında film izleme deneyimi ise bireysel bir izleme deneyimini temsil etmektedir. Bu izleme deneyiminde beklentiler, sinema salonuna göre düşürülmektedir. Buna karşın zamansal, ekonomik ve diğer izleyicilerin davranışlarına yönelik olumsuz bakış açısı gibi faktörler nedeniyle tercih edilmektedir

Anahtar Kelimeler: Sinema, Yeni Medya, Yöndeşme, İzleyici Araştırmaları, Film İzleyicisi 


\title{
From Silver Screen To Digital Media: A Research on the Change of Film Watching Experience
}

\begin{abstract}
In this study, in line with the possibilities created by new communications media, the changes in cinema experience and exhibition opportunities were examined. The role and development of exhibition practices in the context of transformation of cinema into an industry is important. While factors such as spending leisure time, going to the public sphere and socializing play a role in people going to movie theaters, film watching spaces have become pluralized in the course of time. These developments require rethinking the preferences and behaviors in experiencing a film. Purpose of the study is to contribute to the literature in terms of create a future-oriented perspective by defining the factors and motivations that cause audiences to see or watch a film in or outside of movie theater. As part of the study, in-depth interviews were conducted with forty-eight students who participated in the screenings at the cinema clubs of six universities in Istanbul, and the findings were subjected to descriptive analysis. It was determined that the cinema clubs were places where the movie watching experience continued, film materials and digital media platforms were shared, and the participants were required to see movies regularly in movie theaters. With the interpretation of the findings, the following conclusions were reached: For participants, going to the cinema is first and foremost a social activity. Participants develop a positive approach towards cognitive, contextual and emotional-integrative factors. In addition, spatial factors come to the fore as a reaction to digitalization. The film watching experience outside the cinema become individualized. In this watching experience, expectations are reduced compared to the movie theatre. After all, it is preferred due to factors such as temporal, economic and negative perspective on the quality of other audiences.
\end{abstract}

Keywords: Cinema, New Media, Convergence, Audience Research, Film Audience. 


\section{Giriş}

İzleyici kavramı tanımlanması ya da belirli kategorilere indirgenmesi güç bir yapıyı temsil etmektedir. Kavrama yönelik farklı yaklaşımlar göz önüne alındığında; 1930'lardan itibaren etki araştırmaları çerçevesinde incelenen izleyici önce medya araçlarının güçlü etkilerine maruz kalan kitlelere indirgenmiş, sonraki yıllarda ise bu indirgemeci ve naif yaklaşıma karşılık sınırlı etki altında kalan ve pasiflikten çıkarak içeriği seçen ve deneyimleyen bir izleyiciden söz edilmeye başlanmıştır (Yavuz, 2015, s. 26-27).

Özellikle 1960'lı yıllardan sonra yapılan akademik çalışmalarla birlikte; Kullanımlar ve Doyumlar Yaklaşımı ile Kültürel Çalışmalar geleneğinin etkisiyle, medya araçlarının etkisini göz ardı etmeden izleyiciyi anlamın üreticisi olarak gören bir anlaysştan söz etmek mümkündür. Kullanımlar ve Doyumlar Yaklaşımı ile; izleyicilerin çeşitli sosyal ve psikolojik ihtiyaçlarını gidermek amacıyla medya içeriklerine yöneldikleri ve bu tercihlerini bilinçli ve gönüllü biçimde yaptıkları ifade edilmektedir. Fakat bu yaklaşım bireylerin kendi öznelliklerini ön plana çıkararak tercihleri şekillendiren ekonomipolitik çerçeveyi ihmal edebilmektedir (Yaylagül, 2014, s. 72). Bu noktada Kültürel Çalışmalar geleneği; alımlama analizi ve kodlama/kodaçımı gibi yöntemlerle medyaya toplumsal ve sinıfsal ilişkiler çerçevesinde bakmakta, medya içeriklerinin tüketilmesinin de üretim sürecinin bir parçası olduğunu öne sürmektedir (Hall, 2001, s. 509).

Sinema-izleyici ilişkisi çok boyutlu ve karmaşık yapıları, süreçleri içermektedir. Bu çerçevede seyircinin filmin tamamlayanı olmasının yanında; başlı başına inceleme konusu olması ve sorunsallaştırılması ancak 1980'lerden sonraya rastlamaktadır. Kullanımlar ve Doyumlar Yaklaşımı ile izleyicilerin sinemaya gitme ve film tüketme pratiklerinin psikolojik arka planı incelenirken 1980'li yıllardan itibaren izleyicinin tarihsel süreç içerisindeki değişimini ele alan tarihselleştirme yaklaşımı ile anlamın üreticisi olarak kabul edildiği alımlama çalışmaları göze çarpmaktadır (Mayne, 1993, s. 43). Bu yaklaşım; etki araştırmalarını hatırlatacak biçimde pasif izleyiciden aktif izleyici düşüncesine bir geçişi temsil etmektedir.

21. yüzyılda yeni medyanın etkisiyle görünür hale gelen yeni iletişim ortamları, özellikle izleyici ile medya arasındaki ilişkide değişikliklere neden olmaktadır. Yöndeşme kavramı çerçevesinde; farklı araçlar üzerinden deneyimlenen medyalar bir araya gelmekte, bilgisayarlaşma ve enformasyon 
artışı ile izleyiciler kendi istedikleri içeriklere rahatlıkla ulaşabilecekleri bir üretim pratiğinin içerisinde yer almaktadırlar. Bahsi geçen değişim, sinema alanında da hissedilmekte ve film izleme deneyiminin parçalanmasıyla sonuçlanmaktadır.

Film izleme deneyiminin zamandan ve mekandan bağımsız bir yapıya sahip olduğu görülmektedir. İnternetin yaygınlaşması ve servis sağlayıcıların hızındaki artış sonucunda ortaya çıkan video platformları, sektör ve izleyici nezdinde alışkanlıkları değiştirmektedir. Bu yenilikler, bir taraftan da kültürel bir paradigma değişimini temsil etmekte ve sinemanın kolektif yapısını bireysel bir pozisyona çekmektedir. Bir kamusal alan pratiği olan sinemaya gitme deneyimi, sinema salonu dışında film izleme deneyimi tarafından kuşatılmakta ve sektörde bu yönde radikal değişimlere kapı aralanmaktadır. Bahsi geçen belirsizlik ortamı; sinema endüstrisinin ve film izleme alışkanlıklarının geleceğinin şekillenmesinde izleyicilerin çeşitli izleme biçimlerini neden ve nasıl tercih ettikleri konusunda bir problemi ortaya çıkarmaktadır. Bu problemin ortaya konulması ve üzerine düşünülmesi sadece gelecekteki değişim açısından değil, tüm gelişmelere rağmen günümüzde neden hala sinema salonlarında film izlediğimiz sorusunun cevaplanması açısından da önemlidir.

Çalışma kapsamında İstanbul'da bulunan altı üniversiteden sinema kulüplerine üye veya gösterimleri takip eden öğrencilerle derinlemesine görüşmeler yapılmıştır. Çalışmanın örneklem kapsamının belirlenmesinde sinema kulüplerinin hem bu alana özel ilgi duyan bireyleri bir araya getirme potansiyelinin olması hem de alternatif bir izleme deneyimi sunarken üyeler arası film ve görüş paylaşımını sağlayan bir alan yaratması etkili olmuştur. Öğrencilerle yarı yapılandırılmış ve dört başlıktan oluşan bir soru formu üzerinden derinlemesine görüşmeler yapılmış, demografik bilgilerin yanı sıra sinema salonunda ya da sinema salonu dışında film izleme deneyimi ve kişisel pratikler sorgulanmıştır. Çalışmanın İstanbul ile sınırland1rılmasında Türkiye'de satılan biletlerin \% 32'sinin bu ile ait olması (TÜIK, 2020) ve birçok festivale ev sahipliği yaparak kesintisiz bir izleme deneyimi sağlaması belirleyicidir. 


\section{Dünyada ve Türkiye'de Sinema-Yöndeşme İlişkisi}

Medya alanındaki dijitalleşmenin en önemli sonuçlarından biri, izleyicilerin medya ürünleri ile kurdukları ilişkinin değişmesidir. Birer koda dönüşen verilerin iletilmesinde eşzamansızlık, etkileşim ve kitlesizleştirme gibi unsurların ön plana çıkması ile medya alanında parçalanmadan söz edilebilmektedir (McQuail, 2005, s. 371). Bugün farklı medyalara ait özelliklere, farklı araçlar üzerinden ulaşmak mümkün hale gelmiştir.

Yöndeşme temel olarak; toplu iletişim hatları ve araçları arasındaki ayrımın muğlaklaşarak ayrı yollarla sağlanan hizmetlerin bir araya gelmesi ve oluşan yeni sistemlerin günümüzde özellikle internet üzerindeki platformlarda hızlıca büyümesini ifade etmektedir (Pool, 1983, s. 23). Yöndeşme kavramı çerçevesinde medya sektörü ve kullanıcı-izleyici ilişkileri olumlu ve olumsuz yaklaşımlara konu olmaktadır. Bir taraftan yöndeşme; izleyicileri kullanışlı birer tüketiciye çevirme imkanı sağlarken, diğer taraftan onları birer kullanıcıya dönüştürmekte ve ürünlerin tüketilmesinden çok değiştirilmesi anlamında bir demokratikleşme sağlamaktadır (Jenkins, 2006, s. 3; Özen ve Çelenk, 2006, s. 70).

Sinema alanında da benzer bir durum söz konusudur. Bir sanat olmasinın yanında devasa bir endüstriye de dönüşen sinema, bu dönüşümü izleyicisine borçludur. 19. yüzyılın sonunda yapılan ilk gösterimden itibaren sinema, yeniliklere açık ve izleyicisini şaşırtmayı amaçlayan bir atraksiyon niteliğindedir. Teknolojik yenilikler ile sürekli değişen sinema endüstrisi, bir bakıma genç kalmayı başarmıştır.

Film gösterimleri arttıkça ve deneyim sıradanlaştıkça, sinemanın gelişimi bu deneyimi yeniden cazip kılma fikri üzerinden şekillenmiştir. 1990'lı yıllardan itibaren "dijital sinema" kavramının ortaya çıkışı, sinemanın doğuşundaki atraksiyon kimliğini yeniden gündeme getirmiştir. Bu yeniliğin en önemli sonucu daha kompakt, az masraflı ve izleyiciye yepyeni dünyalar sunabilen bir film yapım, dağıtım ve gösterim pratiğinin ortaya çıkmasıdır (Culkin, 2008, s. 45). Ek olarak yaygınlaşan multipleksler, izleyiciye daha konforlu ve teknolojik açıdan gelişmiş bir izleme deneyimi sunarak sinema salonunda film izleme pratiğini canlı tutmaya çalışmışlardır.

Sinema salonu dışında ise; 1990'lı yıllardan itibaren yüksek çözünürlüklü televizyonların ortaya çıkısıı, siyah ekranı beyazperdeye dönüştürme düşüncesini geliştirmiştir. DVD teknolojisi ile birlikte sadece görüntü ve ses 
kalitesi değil, film izleme biçimlerinde de değişiklik gözlemlenmiştir. DVD'lerin sahip olduğu sahne seçimi, kamera arkası görüntüler gibi eklentiler ile farklı bir izleme deneyimi ortaya çıkmıştır (Hilmes, 2009, s. 49). Günümüzde ise aboneliğe bağlı (SVOD), özel içeriklerin seçilebildiği işlemsel (TVOD) ya da ücretsiz olmasına karşın reklam destekli (ADSS) platformlar; parçalı bir film izleme deneyimini sağlarken, içeriği mekandan ve zamandan bağımsızlaştırarak farklı deneyimlerle birleştirmektedir (Ulin, 2010, s. 45-46). Yöndeşme ile farklı formattaki içeriklerin farklı araçlara taşınması, yasal olmayan bir takım film izleme pratiklerini de ortaya çıarmıştır. İnternetin yarattı̆̆ imkanlar ile kopyalanan filmler, torrent ve ücretsiz web siteleri üzerinden de yayınlanmakta ve sektör içerisinde bir mücadele alanı yaratmaktadır.

Türkiye'de ise televizyonun ancak 1970'li yıllarda evlere girmesi nedeniyle sinema, uzun y1llar boyunca özgün bir eğlence biçimi olarak gücünü korumuştur. Sinema salonlarıyla birlikte açık hava sinemaları; köyden kente gelen insanlar için modern hayatın tanınması ve sosyal ilişkilerin kurulması yolunda önemli bir imkan sunmuştur (Akbulut, 2016, s. 237-249; Arslan, 2015, s. 206-207). 1970'li yıllarda televizyonlu ev sayısının artması ve 1980'lerde videokasetlerin yaygınlaşmasıyla birlikte, siyasi çalkantılar ve terör sorunu nedeniyle sinemanın izleyici kitlesi azalmış ve değişime uğramiştır.

1990 'l y yllardan itibaren ise sinemaya yönelik artan talep; salonların multiplekslere ve AVM'lere taşınmasıyla tüketim kültürü ile bütünleşmiş (Tüzün, 2013, s. 105), dijitalleşme ile izleyiciye yeni bir eğlence türü sunulmuştur. AVM'lerin yaygınlaşması ve bu alanlarda açlan sinema salonlarının nicelik bakımından diğer salonları geride bırakması, özellikle kentte yaşayan sinema izleyicisinin film izleme pratiklerini dönüştürmüştür (Özsoy, 2017, s. 359-362). Tanrı̈ver' in (2011) araştırması da kentli sinema izleyicisini; sosyo-ekonomik düzeyi yüksek, iyi eğitim görmüş, genç, kentlerin merkezine yakın yerlerde yaşayan ve şehir hayatının pratiklerini kendi deneyimleri ile bütünleştirmiş bir demografik kitle olarak tanımlamıştır.

Sinema salonları dışında ise şifreli yayınlar ve dekoderler ile özdeşleşen gala geceleri, zamanla herkesin uygun ücretler karşılığında ulaşabileceği video platformlara taşınmaktadır. Bu platformlara Netflix, BluTV ve Amazon PrimeVideo örnek olarak verilebilir. Ücretli platformlar dışında Türkiye'de de film izleme siteleri ve Torrent cazip tercihler haline gelmiştir. 
2020 yılının Mart ayından itibaren Türkiye'yi de etkisi altına alan COVID-19 virüsü'; sağllktan ekonomiye, sosyal yaşamdan kültürel aktivitelere dek birçok alanda önemli değişimlere neden olmuştur. Bu dönemde insanların bir araya geldikleri birçok etkinlik, sempozyum ve festival iptal edilirken, düzenleyici kurumların bir kısmı çalışmalarını dijital ortamlara taşımak zorunda kalmışlardır. Ortaya çıkan bu durum; hem dijital ortamların sanat aktivitelerine ev sahipliği yapma potansiyeli üzerine düşündürmekte hem de var olan geleneksel etkinliklerin geleceği üzerine endişelere yol açmaktadır. Sinema alanında da salonların kapatılması, birçok filmin gösteriminin ertelenmesi, festivallerin ${ }^{2}$ ve bazı filmlerin ilk gösterimlerinin dijital platformlara taşınması endüstri içerisinde bir tartışma yaratmaktadır. Türkiye'de sinema salonları hijyen önlemleri alınarak ve sınırlı sayıda izleyiciye izin verilerek 6 Ağustos 2020'de açılmış, fakat vaka sayılarının artmasi nedeniyle 20 Kasim 2020'den 31 Aralık 2020 tarihine dek yeniden kapatılmıştır. Bu sürecin en önemli sonucu; dijital platformların abone sayısındaki artış ve sinema salonunda film izleyen insan sayısındaki dramatik düşüştür. ${ }^{3}$ Açık hava sinemaları ve arabalı sinemalar gibi uygulamalarla izleyiciler yeniden kazanılmaya çalışılsa da, uzun vadede sürdürülebilir bir yapıdan söz etmek mümkün olmamaktadır.

İzleme alışkanlıklarındaki değişimin pandemi aracıllı̆ı̆yla daha belirgin hale gelmesi ile sinema salonunda film izleme deneyiminin devamlılı̆̆1 tartışma konusu olmaktadır ${ }^{4}$. Örneğin; dijital platformların izleyicilere belirli bir içerik sunması ve izleyicinin de abonelik ücreti ödeyerek bu sınırlı

\footnotetext{
12019 yılının Aralık ayında Çin Halk Cumhuriyeti'nde keşfedilen COVID-19 ya da koronavirüs hastalığı, 2020 yılının ilk aylarından itibaren tüm dünyaya yayılarak küresel bir pandemiye yol açmıştır. Türkiye'de de ilk vakanın varlığı, 10 Mart'ı 11 Mart'a bağlayan gece açıklanmıştır. O günden 2020 yılının Kasım ayına kadar geçen süreçte resmi sayılara göre Türkiye'de 420 binin üzerinde vakaya, 10 binin üzerinde ise ölüme rastlanmıştır.

${ }^{2}$ Bu süreçte Başka Sinema, dağıtımını yaptığı filmleri Blu TV platformu üzerinden belirli bir ücret karşılığı satışa sunmuş, İstanbul Film Festivali çevrimiçi gösterimler düzenlemiş, iptal olan birçok festival We Are One: A Global Film Festival adı altında Youtube'da gösterimler düzenlemişlerdir. "Dune" ve "No Time To Die" gibi önemli gişe filmlerinin vizyon tarihi ertelenmiştir (y.n.)

${ }^{3}$ Netflix, Disney +, Hulu ve Amazon gibi dijital platformlar pandemi sürecinde Nisan 2020 itibarıly abone sayılarını bir önceki yıla göre yüzde 47 artırmışlardır (Liyin, 2020). Buna karşın Türkiye'de sinema izleyici sayısı 2019 genelinde 59 milyon kişi civarındayken 2020 Kasım ayı itibarılla ancak 16 milyon civarına ulaşabilmiştir (Box Office Türkiye, 2020). Sinema salonlarının yıl sonuna kadar kapatılmasıyla da bu sayıda bir değişim beklenmemektedir (y.n.).

${ }^{4}$ COVID-19 pandemisinin sinemada film izleme deneyimine olan etkisini inceleyen bir bilimsel çalışmaya rastlanmamışır. Var olan pandemi ortamından dolayı sahaya inmenin riskli olması da bu durumu yaratan etmenlerin başında gelmektedir (y.n.).
} 
içeriği tüketme eğiliminde bulunması, sinema salonlarının farklılaşmak adına sinema dışı etkinliklere de kapı aralayabileceği düşüncesini doğurmaktadır (Lowe, 2020). Diğer taraftan sinemanın yarattığ kolektivitenin ve sosyalleşme pratiklerinin, film izleme düşüncesini aşan bir yapısının olduğu da söylenebilir (Akbulut, 2020a). Bu noktada sinemada film izleme deneyiminin maliyeti ile sinema salonu dışında film izlemenin avantajları arasında bir çatışmanın ortaya çıkması muhtemel olacaktır (Akbulut, 2020b). Bu açıdan en azından pandeminin gerilemesi ya da bitmesi halinde sinema salonları ile dijital platformlar arasında bir yeni iş modelinin kurulması ve seyir pratiğinin çoğullaşması zaruri görülmektedir (Erkılıç, 2020).

\section{Sinema Salonunda Film İzleme Deneyimini Tanımlamak}

İzleyicinin sinema deneyimini üç başlık altında incelemek mümkündür: Sinemaya gitme eylemi ve bu eylemin arkasındaki motivasyonlar, mekan kaynaklı teknolojik ve mimari deneyim ve izleyicinin beyazperde ile olan ilişkisi.

Sinemaya gitme eylemi, kamusal alana çıkmayı ve hareketliliği temsil etmektedir. Habermas (2004, s. 95); kamusal alanı, tüm yurttaşların erişebildiği ve özel bireylerin kamusal bir gövde oluşturarak toplandıkları her konuşma durumu olarak tanımlar. Egemen kamusal alan düşüncesine karşın Negt ve Kluge (2004, s. 133) tarafından ortaya atılan proleter kamusal alan kavramı ise; ancak egemen kamusal alan düşüncesinin çatlaklarından sızabilen ve marjinal durumlardan kendini kurmak zorunda olan bir tecrübe istemini simgelemektedir. Bu düşünceye göre proleter kamusal alan; emek mücadelesine ve üretim ilişkilerine dayanan, alternatif potansiyeller içeren bir süreçtir. Fakat bu potansiyelin yeni ve güçlü kültürel politikalara dönüşememesinde, özellikle elektronik medyaların iktidarın elinde olması önemli rol oynamaktadır (Hansen, 2004, s. 145). Sinema ise ilk kez ortaya çıtı̆̆ dönemde işçilerin ve göçmenlerin ilgisini çekmesi sebebiyle, bu proleter kamusal alan potansiyelinin serpileceği bir alan olarak görülmüştür. Film ile izleyici arasında bir çağrışım akışından söz edilmekte, kamusal mekan olarak salonda bir araya gelen kolektif izleyicinin özerk hareketi ve öz güvenilirliği cesaretlendirilmektedir (Süalp, 2004, s. 671). Fakat bu yeni alan da gündelik yaşamın ötesine geçememiş ve endüstri alanında yaşanan hızlı 
değişimler sonucunda, sinemada bir proleter kamusal alan yaratma düşüncesi sekteye uğramıştır.

İnsanları sinemaya gitmeye yönlendiren nedenlerden ilki, boş zamanı değerlendirme ve eğlenme isteğidir. Sinema; yaygınlaşmaya başladığ dönemlerde özellikle işçilerin ve göçmenlerin dikkatini çekmiş, ucuz bir eğlence biçimi olarak opera ve tiyatro gibi daha yüksek sanat dallarını ikame etmiştir. Yıllar içerisinde her sınıftan insanın kamusal alana çıkış pratiğine dönüşen sinemaya gitme eylemi; sokakları arşınlayan, diğer insanlarla film izlemeyi arzulayan, filmden önce ve sonra etkileşime giren izleyiciler için sosyal bir uygulama halini almıştır. Sinemaya giden bireyler kendi hayat tarzlarını ve kişilik özelliklerini kamusal alana taşıyarak düzenleme imkanu bulurlar (Hansen, 1991, s. 107).

Sinemanın sürekli tekrarlanan bir pratik olması, onun kurumsal yönünü akla getirmektedir. Jarvie'ye (2013, s.14) göre; sinema sosyal bir kurumdur ve bu kurumun yapısının ortaya çıkarılması için bir filmin tasarlanmasından ve üretiminden satışına, dağıtımına, izlenmesine, deneyimlenmesine ve değerlendirilmesine uzanan kronolojik gelişim takip edilmelidir. Sinema, birey ve toplum ilişkisi üzerinden kitle eğlencesinin sosyal fonksiyonunu sorgulayan bu yaklaşımda, izleyicinin belirli ihtiyaçlarının karşılanması düşüncesi ana değerdir. Estetik değerler ya da sanatsal yaklaşımlar ikinci planda kalmaktadır. Diğer taraftan sinemaya gitme eylemi, belirli psikolojik ihtiyaçları da karşılayan bir etkinliktir.

İnsanları sinemaya yönlendiren motivasyonlar bilişsel, duygusalbütünleştirici ve içeriksel faktörleri kapsamaktadır. Bilişsel faktörler; filmler yoluyla bireyin yaşadığı dünyayı ve kendini tanımasını ifade etmektedir. İzleyici filmler yoluyla olaylar karşısında nasıl davranılacağını anlayabilir, yeni yerler ya da yapılacak eylemler keşfedebilir. Duygusal-bütünleştirici faktörler ise izleyicinin kendi yaşadığı dünyadan kaçış arzusunu ve filmin dünyasına girerek bir bakıma rahatlamasını, özdeşleşme sağlamasını, zaman geçirmesini ve sosyal açıdan bütünleşme yaşamasını temsil etmektedir. İçeriksel faktörler ise filmin konusundan, tekniğinden ya da yönetmenine ve oyuncusuna duyulan beklenti olarak yorumlanabilir. Bu beklenti, motivasyon çalışmalarında "Büyük Beklentiler" (Great Expectations) olarak tanımlanmaktadır. Hayat hakkında bir şeyler öğrenme, gerçeklerden kaçma ve rahatlama, sosyalleşerek yalnızlıktan kurtulma ya da yalnız kalma isteği gibi faktörler, izlenen filmin yarattığı beklentiler ile sınanmaktadır (Austin, 
1986; Katz ve Foulkes, 1962; Mendelsohn, 1966; Palmgreen, Cook, Harvill ve Helm, 1988; Stacey, 1994). Sinemayı özel bir deneyim, neredeyse ritüel olarak kabul eden izleyiciler için duygusal-bütünleştirici faktörler daha çok önem kazanmakta ve bu deneyimi bölen etmenler birer tehdit olarak alg1lanmaktadir.

İzleyicileri sinema salonuna sürükleyen bir diğer unsur ise salonların sunduğu mekana bağlı deneyim ve teknolojik özelliklerdir. İzleyicilerin sinema deneyimi, yer aldıkları çevre içerisinde anlam kazanmakta ve mekanlar çeşitli deneyimler için kendine özgü karakteristikler meydana getirmektedir. Bu bağlamda sinemada film izleyen bir bireyin davranışları, aynı zamanda mekanın da şekillendirdiği davranışlar olarak tanımlanabilir (Ravazzoli, 2016, s. 34). İzleyicilerin yaşadığ1 deneyimi hikayeleştirmesini ve mekana bir "düş şatosu" (Erkılıç, 2009, s. 148) özelliği atfetmesini sağlar. Bu idealize edilmiş mekan anlayışına karşın son yıllarda AVM'lerde yer alan multipleksler ile bağımsız salonlar ${ }^{5}$ arasında bölünmüş sinema mekanları, iki ayrı ucu temsil etmeye başlamışlardır. Bir tarafta gün geçtikçe özel salonları, çiftli ya da loca biçiminde tasarlanarak bireysel izlemeyi yücelten koltukları ve uzay üssü biçiminde bir 1şıklandırmayla büyük boy mısır-kola ikilisi ile sinemayı bire tüketim mabedine dönüştüren multipleksler bulunmaktadır. Görüntü ve ses teknolojilerine yapılan yatırımlarla da izleyiciyi cezbeden bu mekanların karşısında ise; daha çok semte ait olma, geleneksel özelliklerini yeni çağa taşıma, multiplekslerin teknolojik özelliklerine yaklaşamasa da mekanın ruhunu ön plana çıkarma çabasındaki bağımsız salonlar bulunmaktadır. Fakat bu iki mekan deneyimi ne kadar farklı olursa olsun; Medin'in (2017, s. 372) belirttiği gibi geçmişte açık hava sinemaları geleneğinde yer alan karnavalesk ve heterotopik izleme dili yerini daha soğuk ve dispozitif bir izleme biçimine bırakmaktadır.

İzleyicilerin filmle kurdukları bağ, onları sinemaya gitmeye yönlendiren önemli faktörlerden biridir. Sinemaya gitme deneyimi fiziksel ve duygusal bir pratiği işaret etmektedir. İzleyicinin sinemanın doğuşunu takiben filmlerle kurduğu ilişkinin duygusal boyutu ön plana çıkarılmakta; şaşkınlık, şüphe, korku ve inanma gibi duygular arasında gidip gelen bir izleyiciden

\footnotetext{
5 Bağımsız sinema salonu tanımlaması ile herhangi bir sinema salonu zincirine bağlı olmayan, genellikle kentlerin merkezi yerlerine konumlanmış, bir ya da birden fazla salondan oluşan, AVM'lerde yer alan mültiplekslere göre daha uzun süredir hizmet veren sinema mekanları ifade edilmek istenmiştir (y.n.).
} 
söz edilmektedir (Abisel, 1995, s. 7; Balan, 2015, s. 202; Kırel, 2012, s. 18). Aşırı tepkilerin yerini alışkanlığa bırakmasıyla izleyici yeni duygulara yelken açmış, filmler karşısında gönüllü bir pasifliğe yönelmiştir. Karakterlerle özdeşleşme arzusunun yanı sıra, endüstri tarafından birer tüketici olarak görülmeleri de izleyicilerin pasif olarak adlandırılmalarına neden olabilmektedir.

Hansen (2012, s. 160), izleyicinin teknoloji aracılı̆̆ıyla modern bir kolektif duyusal deneyim yaşadığını iddia eder. Hatta bu duyusal deneyim; üç boyut, interaktif sinema ve sanal gerçeklik gibi uygulamalarla fiziksel bir boyuta da taşınmaktadır. Sinema; insanı kuşatırken onun kendisini keşfetmesini ve hem duygusal hem de fiziksel bir bağ kurarak doğrudan bedensel ve ruhsal bir deneyim yaşamasını sağlamaktadır. Staiger ise (2000, s. 162) kolektif deneyimden ziyade, izleyicinin kişisel çözümleyici davranışını ön plana çıkarır. Kolektif deneyim, izleyiciyi homojen bir kitlenin parçası haline getirme riskini taşımaktadır. Tek bir izleyici tanımlamasından ya da modelinden söz edilemez. Kişinin kendi tercihleri, demografik arka planı ve alışkanlıkları gibi özellikler, izleme deneyimini de belirler. Bu yaklaşım da bizi; Kültürel Çalışmalar geleneğinin de ortaya koyduğu gibi etkin ve çözümleyici bir izleyici tanımına götürür. Günümüzde sinema izleyicisinin konumunu ortaya koyan en iyi kavram interaktivitedir. İzleyici artık çeşitli çevrimiçi ortamlarda aktif hale gelmekte, sinemadaki pasif izleyici davranışı üzerine yeniden düşünme imkanı sağlamaktadır. Bu aktif izleyici tezi, asıl karşılı̆̆ını sinema salonu dışında bulmaktadır.

\section{Sinema Salonunun Dışında Film İzleme Deneyimini Tanımlamak}

Film izleme deneyiminin sinema salonunun dışına taşınması; genellikle sinemaya gitmenin kamusal alana çıkma pratiklerini ve yüz yüze sosyalleşme imkanını göz ardı etmektedir. Bu görüşe karşın yeni izleme deneyimi, farklı sosyalleşme ortamları kurulmasını da sağlayabilmektedir. Bir film tekil olarak izlenebilse de o filmle ilgili deneyimlerin paylaşılması için sosyal mecralar kullanılabilmektedir. Her türlü şartta medya tüketmeye yönelik alışkanlıklar, özellikle genç izleyicilerin "platform agnostik" ${ }^{6}$ olarak damga-

\footnotetext{
6 Platform agnostik: Görüntü kalitesi ya da boyutundan bağımsız biçimde her araçta ve platformda medya ürünlerini tüketen ve özellikle $Y$ kuşağı ile ilişkilendirilen bireyleri ifade etmek için kullanılan bir
} 
lanmalarına yol açmaktadır (Tryon, 2009, s. 83). Ekran boyutu, ses ve görüntü kalitesi gibi unsurlara yönelik beklentiler değişirken izleme deneyiminin kendisi mobil hale gelmektedir.

İzleme deneyimindeki parçalanmanın yarattı̆̆ imkanlar, insanların belirledikleri içeriği istedikleri zaman ve yerde tüketmelerine ön ayak olan bir ütopya ile bağdaştırılmaktadır. Ortaya çıkan olanaklar; izleyici tercihlerinin, kişisel beklentiler ve motivasyonlar üzerinden oluşturulmasına neden olmaktadır. (Öz, 2012, s. 72). İzleyiciler medyaya daha fazla entegre olarak çevrimiçi pozisyonlara geçmektedirler. Sinema etki alanını genişletmekte, film izleme hali ise bu deneyimin küçük bir parçasına dönüşmektedir. Dijital araçların sinemaya girişi ile birlikte izleyicilerin kullanıcılara dönüşümü, içerik üretme anlamında daha demokratik bir ortam sağlayabilmektedir. Böylece filmler de kendi bağlamlarından koparak, eğilip bükülebilen ve yeni heterotopyalar yaratan medya içerikleri haline gelmektedir (Atkinson, 2014, s. 101).

Yöndeşmenin ve yeni medya araçlarının seyir deneyimine getirdiği bu ütopik bakış açısına şüpheyle yaklaşan çalışmalar da mevcuttur. İnternete ulaşımda Batılı ülkeler kadar şanslı olmayan bölgelerde ağ erişimi ve telekomünikasyon altyapısı gibi konularda kapsamlı sorunlar çözülmeyi beklemektedir (Abbate, 2017, s. 475). Diğer taraftan zamaninda yeni medya teknolojileri olarak ortaya çıkan basın, radyo ve televizyon gibi araçların hızlı bir biçimde merkezileştirilmesi ve şirketleştirilmesi gibi yeni medya araçlarının da çoklu dağıtım potansiyellerine ve kullanıcı katkısına dayalı içeriklerine rağmen kontrol edilmeye çalışıldığ1 görülmektedir (Maxwell ve Miller, 2011, s. 594). Zaman zaman pazar dışı aktivitelerin susturulmasına ya da sahiplenilmesine kadar giden bir süreçten söz etmek mümkündür (Jenkins, 2006, s. 175). Bu kontrol çabası, üretilen içeriklerin ortak bir bilişsel şablon çerçevesinde bütünleşmesine ve alternatif seslerin susturulmasına neden olmaktadır (Castells, 2008, s. 495-497). Son olarak; talep eden izleyicilerin ücretli olarak izleyebildiği ya da belirli yaş sınırlaması içerisinde piyasaya sürülen içerikler, ahlaki açıdan tartışma konusu olabilmekte ve sansür mekanizması aracılığıyla kontrol edilebilmektedir. Türkiye'de 2019 yılından itibaren dijital platformların RTÜK tarafından denetlenmesi (Öztürk, 2019)

terimdir. Bu yaklaşımın yaygınlaşması halinde sinema ve büyük perde deneyiminin yakın bir zamanda yok olacağına yönelik bir görüş ortaya çıkmaktadır. 
ve Netflix platformunun Aşk 101 (2019, Ahmet Katıksız, Deniz Yorulmazer) isimli dizisine hükümet tarafından müdahale edildiğinin itiraf edilmesi (Gazete Duvar, 2020), yeni seyir ortamlarınin da geleneksel seyir pratiklerinden henüz kopamadığı düşüncesini doğrulamaktadır.

Sinemanin televizyonlara, bilgisayarlara, tabletlere ve akıllı telefonlara entegrasyonu ile perdenin yerini siyah ekranlar almaktadır. Bilgisayar ve taşınabilir (mobil) araçlarla birlikte izleyici ile ekran arasındaki mesafe k1salmakta, araçla olan etkileşim artık dokunma boyutuna ulaşmaktadır. Artan kullanıcı kontrolü ile taşınabilir araçlar üzerinden içerikler hemen her yerde tüketilebilir hale gelmektedir (Lam, 2011, s. 440; Kim, Park ve Yang, 2014, s. 82). İdealize edilen film izleme deneyimlerine rağmen; bilgisayarlaşmanın ve internetin yaygınlaşması ile tercihler, daha küçük ekranlar yönünde yapılmaya başlanmıştır. Çevresel etmenler göz önüne alınarak hoparlör ya da kulaklık aracılığıyla filmin dünyasına giriş sağlanabilmektedir.

Bu gelişmeler sonucunda; film izlemeye yol açan motivasyonlar da değişmeye başlamıştır. Stafford, Stafford ve Schkade (2004), internet üzerinden erişilen içerikler için üç doyumun ön plana çıktığını belirtmektedirler: Bunlar içeriksel, süreçsel ve sosyal doyumlardır. İzlenen medyanın içeriği ve onunla kurulan bağ, içeriksel doyumu temsil etmektedir. Geleneksel medyaların tüketilmesinde de içeriksel doyum önemli bir unsurdur. Medya aracının yapısının değişimi ve erişim kolaylığı, süreçsel doyumda önemli değişikliklerin yaşanmasına neden olmaktadır. Sosyal doyum ise sosyalleşme anlayışının değişmesi üzerinden gözlemlenebilir. Yüz yüze sosyalleşmenin yerini forumlar, sosyal medya uygulamaları ve hızlı mesajlaşma sistemleri almaktadır. Ayrıca kullanıcılar, içerikle ilgili görüşleri için hızlıca sektördeki firmalara ulaşabilmekte ya da sosyal medyada etiketler üzerinden kampanyalar başlatabilmektedir. Kamusal alanda çıkma ve sosyalleşme pratiği, evin içinde ya da dışında bireysel izleme alışkanlıklarına evrilmektedir.

İzleyici ve araç arasındaki etkileşim, yeni izleme biçimlerini de ortaya çıkarmaktadır. Sinema ritüeli, geciktirim süreci adı verilen kavramla tehdit edilmektedir. Geciktirim süreci ile izleyici, dilediği zaman filmin akışını kesintiye uğratarak onun doğrusal yapısını değiştirmekte ve her izleyici içerik üzerinden kendi anlam setlerini oluşturabilmektedir (Mulvey, 2012, s. 32-228). Filmin her sahnesi bağlamından koparılarak ayrı ayrı izlenebilmekte ve ileri-geri sarma özellikleri ile izleyici kendi sıralamasını oluşturabil- 
mektedir. İzleyicinin film akışını durdurarak, ileri-geri sararak anlatıyı çözümleme çabasına girmesi, "düşünceli izleyici" konseptini ortaya çıkarmaktadır. Film izlerken kişisel çözümleyici davranış; araca göre daha baskın ve aktif bir deneyim oluşturmakta, her izleyici için farklı anlamlandırma boyutlarından söz edilebilmektedir. İçeriklerin parçalanması ve anlamlı bütünlere ayrılması ile yeni bir görsel analiz şekli doğarken, izleyiciler birer kaşife dönüşmektedir. Sahne arkası görüntüler, yapım belgeselleri ve röportajlar gibi unsurlar bu keşif çabasına katkıda bulunmaktadır (Bellour, 2012, s. 213).

Sinema deneyimi uzunca bir süre devingen yapısı nedeniyle takipçilerini zorlamış; izleyiciler bir sahneyi ya da sevdikleri oyuncuyu yeniden görmek için tekrar tekrar bilet almak zorunda kalmışlardır. Bu zorunluluğun bir nevi aşılmasını sağlayan "sahiplenici izleyici" konsepti ile bir izleyici filmle ilgili objelere değil, bizzat sahnelere ve karelere sahip olmaya başlamıştır (Mulvey, 2012, s. 191). Bu içeriklerin sahip olunmanın ötesinde manipüle edilmesi, zaman ve mekan boyutunda değişimlere yol açmaktadır. Bu unsurlar taşınabilir, ileri ya da geri alma yoluyla tekrar tekrar deneyimlenebilir.

Sinema deneyiminin değişimi, izleyicinin film öncesinde ve sonrasında davranışlarını da etkilemektedir. Geleneksel medya içerisinde yazılı basının ağır yara alması; kültür-sanat eleştirmenliğini de dönüştürmüş, sosyal medya ve bloglar aracilığıyla izleyicilerin kendi fikirlerini sunması, forumlar oluşturması ve çeşitli uygulamalar üzerinden hap içerikler ve not girmesi mümkün hale gelmiştir. İzleyici artık kullanıcı pozisyonuna geçerek içerik üzerine çalışmakta ve bu çalışmaların internet üzerinden takipçilerine sunarak bir fikir beyanında bulunmaktadır. Sonuç olarak; sinemasal deneyim bir katılımdan çok bir performansı andırmaktadır (Casetti, 2011, s. 89). Bu performansın bireyselleşmesi ise, var olan içeriğin dönüştürülmesini teşvik etmektedir.

\section{Amaç ve Yöntem}

Türkiye'de sinema izleyicisi üzerine yapılan çalışmalar özellikle 2010 yılından sonra artış göstermiştir. Bu artışın birkaç önemli nedeni bulunmaktadır. Sayısal verilerin ön plana çıktığı 21. yüzyılda, Türkiye'deki sinema izleyicisinin sosyo-ekonomik ve demografik özelliklerine ilişkin bir veri tabanının olmaması önemli bir eksiklik olarak görünmektedir. Tanrı̈ver (2011) ve 
Kanzler (2014) tarafından hazırlanan raporlarda Türkiye'deki sinema endüstrisine dair sayısal veriler elde edilmiştir. İzleyiciye dair birtakım sayısal verilerin oluşmasıyla birlikte bu verileri anlamlandırma ve izleme deneyimini oluşturan faktörleri belirleme düşüncesi etkili olmuştur. Bu düşünce aynı zamanda geleneksel seyir deneyiminin değişmesi ve izleme deneyiminin çoğullaşması gibi gelişmelerden de etkilenmiştir. Göker'in $(2017,2018)$ çalışmaları sinema deneyimindeki değişimi sosyallik ve genel kültür bağlamında ele alırken Konukman (2018) ve Karaduman (2018) İletişim Fakültesi öğrencileri örneklemi üzerinden öğrencilerin daha özgür, mobil ve ücretsiz bir izleme deneyimine yöneldiklerini belirtmişlerdir. Diker (2019) ve Medin (2018a, 2018b) ise; dijital yerli veya Y kuşağı izleyicilerin mobil ve akışkan bir seyir deneyimini tercih ettiklerini, karar alma aşamasında sosyal medyadan etkilendiklerini ve tüketim katedrali olarak nitelendirilen AVM'lerin seyir biçimine etki ederek izleyicileri homojenleştirdiğini öne sürmüşlerdir. Bahsi geçen tüm çalışmalar anket ve/veya derinlemesine görüşme yöntemlerini kullanmışlardır.

Bu çalışmanın amacl; öncelikle tarihsel süreç içerisinde izleyicileri sinema salonunda film izlemeye yönlendiren pratikleri ve motivasyonları belirlemek, sonrasında ise günümüzde dijital ortamlar üzerinden yaygınlaşan sinema salonu dışında film izlemeye yol açan unsurlarla karşılaştırmaktır. Benzerliklerin ve farklılıkların ortaya konulmasıyla yakın gelecekte izleme deneyiminin ne yönde şekillenebileceği sorusuna yanıt aranacak, sinema salonlarının bu deneyimdeki rolü üzerine bir değerlendirme yapılacaktır.

Çalışmanın amacına yönelik belirlenen üç araştırma sorusuna yanıt aranarak katılımcıların film izleme pratiklerini "neden" ve "nasıl" şekillendirdikleri sorgulanmıştır. Elde edilen nitel veriler doğrultusunda, seçici izleme deneyiminin ${ }^{7}$ hangi yargılardan ve faktörlerden etkilendiği analiz edilmiştir. İzleyici motivasyonlarının belirlenmesi için Kullanımlar ve Doyumlar yaklaşımını 21. yüzyılda yeniden değerlendiren çalışmalardan yola çıkılarak kuramsal bir çerçeve oluşturulması hedeflenmiştir. Stafford, Stafford ve Schkade'nin (2004) internetin tüm medyalar için merkezi konuma gelmesiy-

\footnotetext{
7 Seçici izleme deneyimi: İleyiciler medya araçlarını ve içeriklerini tercih ederken sahip oldukları değer yargılarından ve alışkanlıklardan hareket ederler. Güçlü etkiler yaklaşımından çok yapılan tercihler üzerinden bir doyuma ulaşma çabası gözlemlenmektedir. Kullanımlar-doyumlar ilişsisi bu noktada sağlanmakta ve bu yaklaşıma seçici izleme deneyimi adı verilmektedir (McQuail ve Windahl, 2010, s. 166).
} 
le ortaya koyduğu içeriksel, süreçsel ve sosyal doyum yaklaşımlarından da faydalanılmıştır.

$\mathrm{Bu}$ çalışmada derinlemesine görüşme yöntemi uygulanmıştır. Derinlemesine görüşme; yüz yüze ya da birebir görüşme sonucunda bilgi edinmeye yöneliktir ve katılımcıların gerçek yaşamlarına ait tecrübelerinin ve duygularının, görüşmeci ile kurdukları etkileşim sonucunda anlamsal olarak yeniden inşa edildiği bir yapıyı ifade etmektedir (Tekin, 2006, s. 101). Derinlemesine görüşme, görüşülen kişiyi daha özgür kılmakta ve herhangi bir sınırlandırmaya tabi tutmamaktadır. Fikirlerin sınırlandırılmadan rahatça iletilmesi ve hılıca bir geri besleme imkanının yaratılması sonucunda çözümlenebilecek birtakım nitel verilere ulaşılması mümkün olmaktadır (Jensen, 2005, s. 132).

Görüşme için yarı yapılandırılmış 34 soruluk bir form hazırlanmıştır. Bu sorular dört başlığa ayrılmıştır: Katılımcıların yaşı, cinsiyeti, kültürel faaliyetlere ve sinema salonunda aylık film izleme sayılarını içeren demografik sorular, sinema salonunda film izleme deneyiminde yaşananlar, salon haricinde film izleme deneyiminde yaşananlar ve film deneyimi sonrasındaki aktiviteler. Görüşmelerin ses kaydı alınmış ve deşifresi yapılmıştır.

\section{Örneklem}

Çalışmanın evreninin ve örneklemin belirlenmesinde; herhangi bir medya aracı söz konusu olduğunda, o aracı sıklıkla kullananların seyrek kullananlara göre daha fazla sayıda motivasyona sahip olduğu düşüncesinden yola çıkılmıştır (Lichtenstein v.d., 1983). Bu çalışmada kullanılan üniversite öğrencileri evreninin uygunluğunu anlayabilmek için önceki çalışmalar yol gösterici olmuştur. Üniversitelerde eğitim gören öğrencilerin sinemaya sık gitme konusunda diğer yaş ve eğitim gruplarının çok üzerinde olduğuna yönelik birçok çalışma bulunmaktadır (Kanzler, 2014, s. 112; Tanriöver, 2011, s. 135; Yavuz, 2012; Göker, 2017, s. 442; 2018, s. 278).

Üniversitelerde yer alan sinema kulüplerinin varsayımsal olarak sürekli film gösterimi yapan ve izleme deneyiminin sürdüğü yerler olduğu düşünülmüştür. Bu düşünceden yola çıkılarak belirlenen sinema kulüplerinin başkanları ve üyeleriyle ön görüşmeler yapılmış, faaliyetler ve üyelik aktiviteleri üzerine bilgi alınmıştır. Yapılan görüşmeler sonucunda sinema kulüplerinin düzenli gösterimler yaparak toplulukla film izleme deneyimi sürdü- 
ren ve sinema salonlarına alternatif izleme mekanları yaratan yapısı ön plana çıkmıştır. Buna ek olarak sinema kulübü üyeleri kendi aralarında filmleri değiş-tokuş etmekte, ücretli dijital platformlar üzerinde ortak hesaplar açarak kişisel izleme deneyimlerini de sürdürmektedirler. Bu açıdan bakıldığında sinema kulüplerinin alternatif izleme mekanları yaratmanın yanı sıra içeriklere ulaşma açısından da demokratik bir yapıyı temsil ettiği söylenebilir. Özellikle sinemaya ekonomik nedenlerle gidemeyen öğrenciler için sinema kulüpleri, ekonomik problemleri bertaraf etme açısından önem teşkil etmektedir.

Amaçlı örnekleme yöntemi doğrultusunda; üç devlet, üç vakıf olmak üzere (İstanbul, Boğaziçi, Yıldız Teknik ile Bilgi, Kadir Has ve Sabancı Üniversiteleri) İstanbul'da bulunan altı üniversiteden sinema kulüplerine üye ve etkinlikleri takip eden 48 öğrenci ile görüşülmüştür. Bu sayının yeterli görülmesinde amaçlı olarak seçilen örneklemin; çalışmaya azami katkı sağlayabilecek kişilerin seçilmesini hedeflemesi ve bu katkı sağlandığı sürece katılımcı sayısının esnek olabileceği düşüncesinden yola çıkılmıştır (Patton, 1990, s. 169; Aziz, 2008, s. 55).

Sosyo-ekonomik ve kültürel açıdan farklı arka planlara sahip 19-25 yaş aralığındaki öğrencilerin yarısı kadın, yarısı ise erkektir. Farklı cinsiyetlerden öğrencilere eşit ölçüde konuşma şansı verebilmek amacıyla bu yaklaşım tercih edilmiştir. Öğrencilerin farklı bölümlerden seçilmesine önem verilmiştir. Bunun nedeni; Radyo, Televizyon ve Sinema Bölümü'nde okuyan ve sinema ile daha yakından ilişkili olan öğrencilerin görüşlerinin yanında farklı bakış açılarına yer vermenin amaçlanmasıdır. Bu nedenle görüşme yapılan 11 öğrenci Radyo, Televizyon ve Sinema veya benzeri bölümlerden, diğer katılımcılar ise Mühendislik, Hukuk, Öğretmenlik gibi farklı bölümlerden seçilmiştir.

Katılımcılarla görüşmeler 19.12.2017 - 10.05.201989 tarihleri arasında yapılmıştır. İki görüşme Kadıköy'de bir kafede toplam beş katılımcıyla yüz

\footnotetext{
${ }^{8}$ Saha araştırmasının 1,5 yıllık bir süreye yayılmasında çeşitli faktörler rol oynamıştır. Öğrencilere vize, final dönemleri ile sömestr ve yaz tatillerinde ulaşmak neredeyse imkansız hale gelmiş, daha çok sinema kulüplerinin faaliyetleri bu görüşmeler için bir fırsat yaratmıştır. Bu noktada da görüssmelerin 30 dakika ile 1 saat arası sürmesi nedeniyle öğrenciler, görüşme konusunda çekingen kalmışlardır. Bu sorunun çözümü; kampüs seyahatlerinin sıklaştırılması ve öğrencilerin daha rahat hareket ettikleri geniş zaman dilimlerinin kararlaştırılmasıyla mümkün kılınmıştır (y.n.).
} 
yüze yapılırken diğer görüşmeler üniversitelerin kampüsü içerisinde yer alan alanlarda gerçekleştirilmiştir. Bu mekanlar arasında film gösterimi yapılan salonların yanı sıra kantinler, boş sınıflar, kafeteryalar ve açık alanlar sayılabilir. Katılımcıların isimleri bir kodlama sistemiyle değiştirilmiştir. (Örnek: Bilgi Üniversitesi - Kadın - 8 numaralı katılımcı: BİK8, Sabancı Üniversitesi - Erkek - 5 numaralı katılımcı: SÜE5). Betimsel analiz yöntemi ile kaydedilen cevaplar, bir sistem içerisinde analiz edilmiştir. Buna göre öncelikle cevaplar yarı yapılandırılmış soru formunda yer alan dört başlık çerçevesinde gruplandırılmıştır. Sonrasında her sorunun cevapları kendi başına ayrı bir dosya içerisinde kategorize edilerek taranmıştır. Cevaplar benzerliklerine ve farklılıklarına göre yorumlanmış, kapsayıcı ve temsil gücü yüksek nitelikteki içeriklere makalede yer verilmiştir. Cevaplar, makalenin literatür taraması sonucunda oluşturulan giriş bölümünde değinilen konular dikkate alınarak yorumlanmıştır.

\section{Bulgular}

Görüşme yapılan katılımcılara ayda kaç kere sinema salonunda film izledikleri sorulmuş ve yüzde 72'si “2 ya da 3" cevabını vermiştir. Yüzde 17'si “4 kere", yüzde 11'i ise "1 kere" sinema salonunda film izlemektedir. Türkiye'de bir yılda kişi başına satın alınan bilet sayısının 0,710 olduğu düşünülürse, görüşülen katılımcıların sinemaya gitme sayıları Türkiye ortalamasının üzerindedir. Bu rakamın yüksek olmasında katılımcıların üye oldukları ya da gösterimlerini takip ettikleri sinema kulüpleri aracılı̆̆ıyla sinemayı hayatlarının vazgeçilmez bir parçası yapmalarının etkisinden söz edilebilir.

Görüşme yapılan katılımcıların sinema salonu tercihlerinde AVM'deki multipleksler ilk sirada gelmektedir. Bu salonları tercih etmelerinde; AVM'lerin merkezi konumları, sahip oldukları teknik standartlar ve AVM'deki diğer tüketim aktiviteleriyle sinema ve sosyalleşme deneyimini birleştirme arzusu etkili olmaktadır. Ayrıca AVM'lerdeki sinema ortamı ile ev ortamı arasında doğrusal bir bağlantı kurulmaktadır:

\footnotetext{
${ }^{9}$ Görüşme yapılan tarihler COVID-19 pandemisini öncelediği için görüşmelerde bu konuya değinilmemiştir. Bu açıdan çalışmanın COVID-19 pandemisi öncesi dönemde film izleme deneyimini ele aldığı söylenebilir (y.n.).

10 TÜiK'in hazırladığı "Sinema ve Tiyatro Istatistikleri 2019" raporuna göre Türkiye'de kişi başına düşen yıllık bilet sayısı 0,7'de kalmaktadır. Sınırlamayı ayda 1 kez üzerinden kurmak, yıllık ortalamanın oldukça üzerinde bir sıklığı sağlamaktadır.
} 
“...bazı gişe filmlerini AVM sinemalarından izliyorum. Çünkü bazı bağımsız sinema salonlarn gerek görüntü, gerekse ses kalitesiyle bu tarz filmlerin gerektirdiğ $i$ teknolojik yeterliliğe sahip değil ne yazık ki." (BÜE2)

"Benim için salonun teknik olarak görece yeterli olması ve mimari olarak boğucu olmaması birinci strada önem arz ediyor. Tavan alçak, ferah olmayan salonlar tercih etmiyorum. Ikinci strada ise kolay erişilebilirlik, salon konforu gibi faktörler tercihlerimde rol oynuyor." (BIE1)

Multiplekslerin dışında kalan bağımsız salonlar ise genellikle ekonomik ve politik sebeplerle tercih edilmektedir. Bilet fiyatlarının uygunluğu ve bu mekanlardaki yaşanmışlık hissi, filmle kurulan iletişime de katkıda bulunmaktadır:

"AVM'de izleyicilik başka bir şeye dönüştü. Insanlar film izlemeye değil de bir şeyler tüketmeye geliyorlar ve filmler de bunlarn bir parçası haline geliyor. Haliyle nasıl tükettiğinin bir önemi kalmıyor, bazen saygısızca davramilyor. Bağımsız salonlarda da sorunlar oluyor ama bu seviyede değil bence. Orada hala asıl odaklantlan şey filmin kendisi oluyor." (SÜE4)

"Açıkçası bağımsız salonları tercih etmeye çalışıyorum çünkü şehrin geçmişini, dokusunu taşıyan yerler. Geçtiğimiz yıllarda Beyoğlu Sineması için bir mücadele verildi mesela, işte Sadakat Kartı çıkardılar. O dönem almıştım, şimdi yok ama gitmeye çalışıyorum." (YTK3)

Günümüzde sinemaya gitme deneyimi, internete ve sosyal medyaya entegre hale gelmiştir. Sinemaya gitme pratikleri ilk bakışta kamusal alanı ve bütüncül bir izleme deneyimini temsil etse de bugün bu unsurlar tüketilebilir bir içeriğe dönüşmektedir. Filmle ilgili bilgiler almak, reklamlarda ve arada mesajları kontrol etmek ve filmden sonra eleştirileri okumak gibi hareketlerin yanı sıra sinemaya gidecek birilerini bulmak ve sosyalleşmek düşüncesi de yeni iletişim ortamlarından geçmektedir:

"Sinemaya gittiğim filmlerin çok büyük kısmın vizyona girmeden önce bekliyorum. Sinematografisinden, senaryosundan, yönetmeninden ya da oyuncusundan ötürü. Ama bu kıstaslar dışında gittiğim filmler için arkadaşlar ya da sosyal medyadan bilgi alyyorum. Bazı internet sayfaları güzel bir perspektif oluşturabiliyorlar. Haberim oluyor bazı filmlerle ilgili. Mesela çok beklediğim bir film vardır ama o film çok eleştiriliyordur, o durumda sinemaya gitmiyorum. İnternete düşünce izliyorum." (YTE1) 
"Telefon genelde titreşimde duruyor, mesaj falan gelse bakmam. Filme de biraz bağlı galiba. 'Sinemaya gitmeye değer' dediğim bir filmse ona daha çok odaklanıyorum." (İ̈̈E3)

Duygusal ve bilişsel faktörler izleyicinin içerikle olan ilişkisini belirlerken günümüzde mekana bağlı faktörlerin önemli bir rol oynadı̆̆ı gözlemlenmektedir. Bunun yanı sıra; katılımcılar film tercihlerinde daha seçici olmakta ve "Büyük Beklentiler" motivasyonu ile bazı filmlere öncelik tanımaktadırlar. Sinema salonuna gitme fikri her geçen gün salon dişı deneyimlerle tehdit edilirken, sinema salonunda beklentilerin karşılanması daha fazla önem kazanmaktadır:

"Karanlık bir salonda, büyük bir perde karşısında olmak ve ses sistemiyle çevrilmek, izleyicinin diş etkenlerden soyutlanarak filme daha aktif bir şekilde dâhil olmasını, daha detaylı ve dikkatli bir film izleme-okuma deneyimi yaşamasın sağlıyor. Bu bakımdan sinema salonunda film izlemekle pek çok diş uyaranın olduğu evde film izlemek arasında çok büyük bir fark olduğunu düşünüyorum." (İ̈̈E2)

"Sinema deneyimi bambaşka bir şey olmalı bence. Filmi yatakta bile izleyebilirsin ama sinema salonunun kokusu, bıraktığı iz ve onlarca insanın oradan geçmiş olması özel bir olay. Senin bu sürece katılıyor olman da öyle. Duvarlarm dili olsa neler anlatır yani. Deneyim yapan şey budur aslında, getirdiği bir birikim var ve sen de buna dahil oluyorsun." (YTE3)

Sinemaya gitme pratiği, sosyalleşme bağlamında ele alınmakta ve film izlerken de duygusal bulaşıcılıktan söz edilerek farklı bir sosyalleşme deneyiminden söz edilmektedir. Diğer izleyicilerin sinema salonundaki davranışları, katılımcıların deneyimini olumlu olduğu kadar olumsuz biçimde de etkilemektedir. İzleyiciler özellikle AVM'lerde yer alan multiplekslerde olumsuz davranışları daha sık gördüklerini belirtmekte ve bu sinemalarda film izlemeye gelen izleyiciler için filmin içeriğinin ya da salon ambiyansının arka planda kaldı̆̆ından şikayet etmektedirler:

"Belli bir anda, belli bir amaçla bir arada oturan bir topluluk var. Yalnız olmadğım hissediyor insan, toplu bir aktivite var ve bireysellikten çıkıorsun. Bunun bir değeri var yani. Biriken kültür de bu insanlarn ayn yerde toplanmasıyla ilgili." (YTE3)

"Kimsenin kimseye saygısı ve kişisel alan algısı olmadığ için o salon, mısır patlakları, çocuk çı̆̆lıklarn instagram storyleri ya da mesaj sesleri ile dolu 50-60 kişilik bir deneyime dönüşüyor." (İ̈̈K1) 
Sinema deneyimi içerisinde yer alan 10 dakikalık ara, jenerikler ve reklam sekansları sinema deneyiminin bir parçası olmaktan çok çevrimiçi dünyaya bağlanmak için bir fırsat oluşturmaktadırlar. Bazı izleyiciler jenerik sonuna kadar beklemeyi tercih etmektedirler. Diğer taraftan fragmanlar; sonraki haftalarda vizyona girecek filmlerle ilgili yarattıkları beklentiler ile film haricinde en ilgi çekici bölüm olarak nitelendirilmekte ve çevrimiçi araçlar bir kenara bırakılmaktadır:

"(10 dakikalık ara) Gerekli değil ama o aranin geleceğini bildiğiniz için alışıyorsunuz. Bir de şu açıdan önemli, insanlar telefona bağımlı yaşıyorlar. Birçoklar için 30 dakika bile telefonsuz çlldırmak için yeterli bir süre. En azından 10 dakikada o heveslerini gideriyorlar. Yoksa film süresince telefonuna bakan onlarca insan daha çıkardı yani." (KHE3)

"Son zamanlarda reklamlar seans saatinden bile erken başlar oldu, o nedenle ne yaparsan yap bir şekilde karşına çıkıyor. Genelde telefonumla ilgilenirim ya da yanımdakiyle konuşurum ama fragmanlara dikkatimi veririm." (BİE4)

Bir filmi tercih etme noktasında katılımcilar ilk olarak filmin "niteliğine" bakmaktadırlar. Burada bahsi geçen nitelik kelimesi; filmin hikayesinin, yaratıcı ekibinin ve gündemde kapladığı yerin izleyici üzerindeki etkisi olarak düşünülebilir. Ancak biletlerin pahalı olması, havanın şartlarının kötüleşmesi, izleyicilerin kalitesinin düşük bulunması ve sinemaya gidecek birinin bulunamaması gibi durumlarda katılımclar sinemaya gitmemeyi tercih edebilmektedir:

“İlk baktığım şey filmin yönetmeni oluyor aslında. Daha sonra da oyuncu kadrosu. Ĕğer bu iki faktör benim için tatmin ediciyse filmi izlemek için başka bir kritere ihtiyaç duymuyorum." (BÜE2)

"Genel olarak gitmek istediğim bir film varsa giderim, gitmiyorsam da tek sebebi benimle gidecek birini bulamamamdır." (SÜE2)

Katılımcıları hepsi sinema salonu dışında film izlemektedir. Film izlemede en fazla benimsenen uygulama ve platformlar Ücretsiz İsteğe Bağlı Video, Torrent ve Aboneli İsteğe Bağlı Video'dur (bkz. Tablo-1). İnternete ve uygulamalara doğrudan bağlantı imkanı verirken taşınabilir olmasıyla bilgisayar ekranı en çok tercih edilen ekran çeşididir. Onu yüksek çözünürlüğe sahip televizyon izlemektedir (bkz. Tablo-2). Televizyonlar görüntü kalitesiyle sinemaya en yakın araç olarak düşünülmekte, bazı katılımcılar HDMI kablo vasıtasıyla bilgisayarlarını televizyona bağlayıp film izlemektedir: 


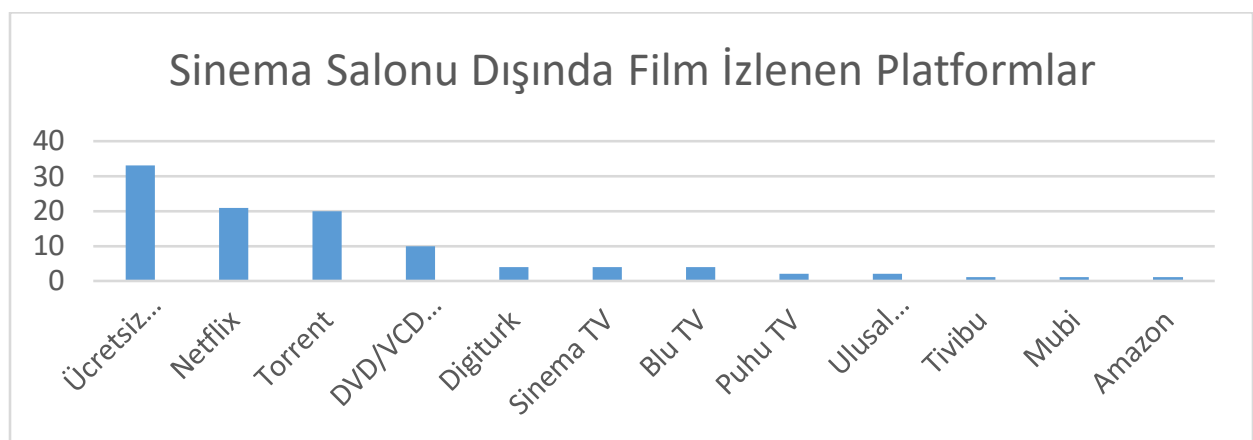

Tablo 1. Sinema salonu dışında katılımcılarn tercih ettiği film izleme platformları

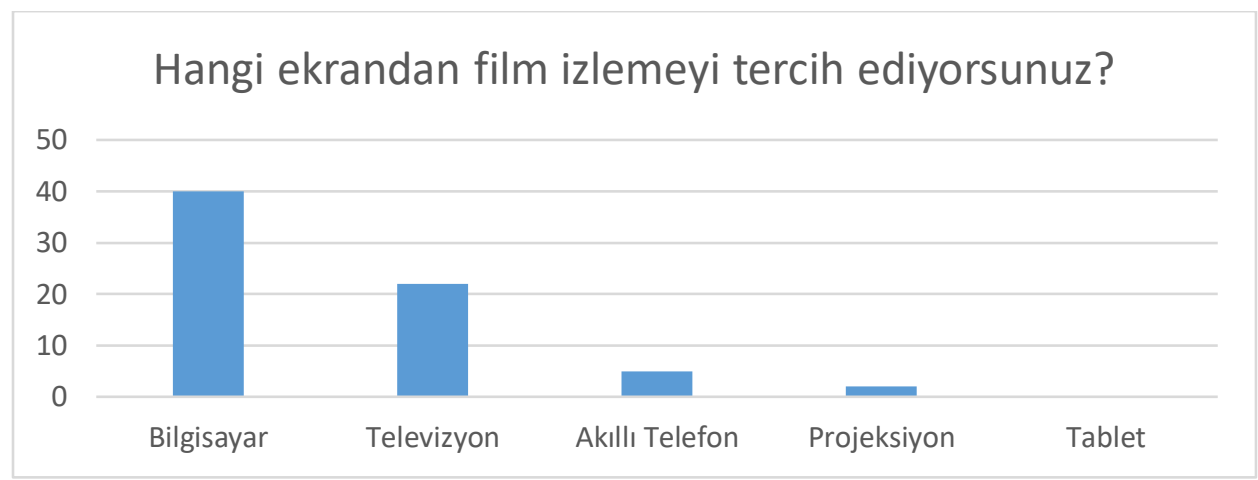

Tablo 2. Sinema salonu dışında katılımcıların tercih ettiği ekranlar

"Ücretsiz siteler en çok kullandı̆̆ım kanallar genelde. İlk başlarda çok sıcak yaklaşmasam da zamanla filmlerin çeşitli platformlara dağılması ya da iyi film bulmanin zorlaşması nedeniyle kendi zeoklerime göre istediğim zaman istediğim filmi izleyebilmek daha önemli bir hale geldi." (BIE3)

"ilk tercihim TV ekranı olsa da son zamanlarda hep bilgisayar üzerinden izlemeyi tercih ediyorum. Film izleme sitelerinden kolayca filmlere ulaşmam nedeniyle." (BÜK4)

Geçmişte daha yaygın kullanılan ev sinema teknolojileri yavaş yavaş yerini daha basit ve kompakt teknolojilere bırakmaktadır. Sinema salonunda film izleme deneyimini kopyalama düşüncesi değişim göstermektedir. Artık teknik imkanların kopyalanmasının yerini daha akıcı ve basit izleme deneyimleri almakta, içeriği tüketme düşüncesi önem kazanmaktadır: 
"Evde de şartlar gereği insan bilgisayar veya televizyon ekranina alışıyor. Beyazperde her zaman bir numaradır, yine de film güzelse küçük ekran da yeterli gelir." (BIK2)

"...büyük perde doğal olarak daha iyi ve içine alan bir deneyim sunarken mesela telefon ekranı çok sinırl. Ama gitgide ona alışıoruz ve beklentilerimiz düşüyor diye düşünüyorum." (KHK4)

Katılımclar temel ihtiyaçlar dışında sinema salonunda film izleme deneyimini bölmezken, sinema salonu dışında sık sık ara vermekte ve geciktirimli izleme deneyimine geçiş yapmaktadırlar. Youtube ve Instagram gibi platformlardaki kısa içerikleri tüketmeye alışan katılımcılar, filmleri de bölerek kisaltmakta; herhangi bir vicdani ya da ahlaki ikilemi de bertaraf etmektedirler:

"Ara veriyorum. Açıkçası baştan sona durdurmadan film izleme olayı bende yok oldu. Film izlerken onunla ilgili ya da ilgisiz aklima bir şey geliyor, internette takulyorum. Bazen iki saatlik film dört saatte bitiyor. Bir haftada izlediğim film bile oldu, parça parça. Hemen bitirdiklerim de oluyor, konu ya da akışla ilgili olarak." (IÜE2)

"Filmden sikulirsam, oyunculuğa tahammül edemezsem, sahneyi tahmin edersem, büyük ölçekli şiddet ya da midemi bulandıracak herhangi bir şey görürsem filmi o sahne geçene kadar ileri sararm." (IÜK1)

Filmlerin parçalara bölünmesi, onların kare kare değerlendirilmesinde ve çözümlenmesinde de etkili olmuştur. Filmler çeşitli repliklere, görsellere ve GIF'lere ${ }^{11}$ indirgenmekte; hap içerikler aracıllı̆ı̆ıla hızlıca yorumlanmaktadır. Bunun sonucunda bazı sahneler, filmlerin bile gücünü aşarak milyonlarca kez izlenmektedir:

"Mesela unutulmaz sahnelere sahip filmlerin bazı anlarnna sürekli dönüyorum. Filmden bağımsız şekilde kurgulanmalarna, repliklere hayranım. Filmlerin tamaminı seviyorum aslında biraz da vakitsizlikten dolayı belirli sahnelere bakı hasret gideriyorum diyebilirim." (BIEE3)

"Şöyle ki bazen bir filmi gerçekten hissederek izliyorsunuz ve bittiğinde size bir şeyler katıyor ama diğger yandan bir film olduğunu zaten fark ediyorsunuz. Bunun gibi filmden sonra izlediğiniz şeyler de "film olma" duygusunu destekliyor. Fakat izlerken aldığını şeylerin etkisinden bence azalma olmuyor. Ĕ̆lenceyse eğlence, dramaysa drama sonuçta." (YTK4)

\footnotetext{
${ }^{11}$ GIF: Grafik Değiştirme Biçimi (Ingilizce Graphics Interchange Format). Sayısal bir resim saklama formatıdır ve piksele dayalı animasyon yapılmasını sağlar (y.n.).
} 
Sinema salonu haricinde film izleme deneyimi ile bireysel izleyicilik ön plana çıkmakta; sinemaya birileriyle giderek sosyalleşme imkanının bulunamaması halinde bu izleyicilik hali daha çok tercih edilmektedir. Bazı katılımcılar özellikle sosyal etkileşimden uzaklaşmak için bu deneyimi tercih etseler de ebeveynleriyle film izleme durumunda sosyal etkileşim kaçınılmaz hale gelmektedir:

"Evde tek izlemeyi severim, vakit geçirmek ya da zaman iyi değerlendirmek için. Ev ortamında nadiren sosyalleşirim, yani toplu film izleme deneyimi beni pek açmıyor." (BÜE1)

"Arkadaşlarmmla nadiren izliyorum, bazen ailemle Digiturk'ten izliyoruz. Kendim çok konuşmuyorum ama ailemden biri bir şey sorar ya da söylerse cevap vermeye çalışıyorum. Çok haz ettiğim bir durum değil ama yine de diğer türlü saygısızlık yapmak istemiyorum." (YTE4)

Sinema deneyimi çeşitli ritüel özelliklerinden koparak rahatlık ve hız üzerinden tanımlanmaya başlamıştır. Bu yeni yaklaşımların yaygınlaşması, geleneksel deneyimin olumsuz olarak algılanmasını beraberinde getirmektedir. Sinema salonu dışında film izleme deneyimi, bazı katılımcılar için neredeyse özgürleştirici bir deneyim sunmakta; istedikleri mekanda ve zamanda içerik tüketme, çeşitli faktörlerden kaçma imkanı yaratmaktadır:

"Daha geniş bir zaman diliminde izleme şansı vermesi, sinemaya göre daha çok yayılmanızı sağlayan bir ortam sunması evin avantajları. Ya da yolda izlemek, bir şekilde vakit geçirmeyi sağlıyor. Istediğin zaman istediğin yerde durumu. Bunlar, filme ulaşmanın kolaylaşması bir avantaj." (BİE4)

"İçeriye çocuk almıyorum, mısır patlatmıyorum, kimseye bir şey yedirmiyorum mesela. Reklam yayınlanmıyor olmasi da büyük nimet bana kalırsa." (İ̈̈K1)

Katılımcılar da kendi belirledikleri bazı filmleri evin rahatlığında izlemeyi tercih etmekte, sinemadan kaynaklanan bilişsel ve duygusal faktörleri bir ölçüye kadar karşılamaktadırlar. İçeriklere kolayca ulaşmak, izleme deneyimini kendi isteğine göre belirlemek, mekanı düzenlemek, ücretsiz ya da düşük bir ücretle içerik tüketmek ve bazı filmleri vizyon tarihinden önce izleyerek bu filmlerle ilgili sosyal medyada ilk yorum yapanlar arasina katılmak vb. motivasyonlardan söz edilebilir:

"Beklediğim bir filmse direkt sinemada izlerim. Kötü eleştiri aldrysa bile giderim. Beklentim her şeyin önündedir. Genelde zaten korku ya da bilimkurgularn tercih 
ediyorum, görsellik öne çıkyor. Dram türünü pek tercih etmem ve bu tarz filmleri internetten izlerim." (İ̈̈E2)

“...genelde ev ortamının ă̆ır basacă̆ını düşünüyorum. Zaten sinema da biraz buraya doğru kayıyor, hepimizde telefon ve internet var. Sinema biraz daha özel bir etkinliğe dönüşüyor, izleme işi ise hep sabit kalıyor." (BÜK2)

"Netflix hesabım olmasına rağmen Roma'yı (2018, Alfonso Cuaron) sinema salonunda izlemiş fakat Organize İşler: Sazan Sarmalı'n (2019, Yılmaz Erdoğan) evde Netflix'ten izlemeyi tercih etmiştim." (BİE1)

Çevrimiçi siteler, forumlar, sosyal medya uygulamaları ve bloglar arac1lığıyla herkes fikirlerini paylaşabilmektedir. Günümüzde görsel-işitsel medyaların yaygınlaşmasıyla birlikte bu görüşler, bireylerin kendilerini de sergiledikleri bir performans haline gelmektedir:

"Halihazırda dikkatimi çeken ve önemli gördü̈̆̈̈m detaylar hakkında farklı yaklaşımlar okumak da aymı şekilde hem fikrimi pekiştirmek açısında ya da eksik kaldığım kısımlarn kavramak açısından önemli olabiliyor. Filmin konu edindiği ve daha önce bilgim olmadı̆̆ı konular hakkında okumalar yapmak ise, filmle birlikte düşünüldü̈̆̈̈̈nde ufuk açıcı bir hal alabiliyor." (BİE2)

"Küçük bir blogumuz var, ̈̈ç arkadaş ara sıra yazıyoruz. Bazen dosya yapıyoruz, belli bir yönetmenden bahsediyoruz. Şimdi işler biraz daha Youtube'a kayd,, orasıla ilgili de planlarmız var." (YTE4)

\section{Tartışma ve Sonuç}

Dijital teknolojiler aracılığıyla sinema deneyiminin çoğullaşması, birden fazla sonucu olan bir paradigma değişimini temsil etmektedir. Çalışmada cevap verilmesi amaçlanan birinci araştırma sorusunda; tarihsel süreçle birlikte günümüzde de izleyicileri sinema salonunda film izlemeye iten motivasyonlar ve izleme pratikleri sorgulanmaktadır. Sinema deneyimi üzerinde etkili olan motivasyonlar arasında duygusal ve bilişsel faktörler ön plana çıkmaktadır. Daha önce yapılan çalışmalar göz önüne alındığında bu çalışmadaki en büyük yenilik, izleyicilerin mekana bağlı faktörlere sürekli vurgu yapmasıdır. Katılımcılar filmlerin gösterildiği mekanlara önem atfetmekte ve kurdukları bağ üzerinden kolektif bir izleme deneyimini övmektedirler. Mekan; filmin içeriği ile film izlemeye dair anıların birleştirilmesinde bir tutkal görevi görmektedir. Sinema salonunun kendine has özellikleri, yaşanan deneyimin de özel bir etkinlik olarak kodlanmasını sağla- 
maktadır. Bu açıdan duygusal ve bütünleştirici ile bilişsel faktörlerden söz ederken mekana bağlı faktörler bir çatı görevi üstlenmektedir.

Sinema deneyiminin karanlıkta, sessizlik içerisinde ve perdedeki görüntüye teslim olunarak yaşandığına yönelik idealize edilmiş bir sinema dispozitifi örneğinin sıklıkla verildiği görülmektedir. Sinema salonunda film izlemek bir kolektif deneyim oluşturmakta ve bu deneyime nostaljik anlam atfedilmektedir. İzleyiciler bazı durumlarda filmlerin içeriğini hatırlamamakta ama salonla kurdukları duygusal bağ üzerinden bir filmi çok daha net biçimde hatırlayabilmektedir. Sinema salonu ile kurulan bağ, onun ritüel özelliklerinden ayrı tutulamaz. Sinema salonlarının yarı resmi kuralları, onu dışarıda izleme deneyiminin sunduğu sonsuz imkanlara karşı özel kılmaktadır. Diğer taraftan; 10 dakikalık ara, jenerikler ve reklam sekansları gibi unsurlar ile film deneyiminin bölünmesi normalleşmekte, davranışlar ise sosyal çevrenin tepkileri ile yapılandırılmaktadır.

Sinema salonları; dijitalleşmenin getirdiği yenilikleri cazip hale getirmek için belirli bir konforu hedefleseler de bu anlayış genellikle izleyicileri farklı kategorilerdeki sinemalara, localara, tekli ya da çiftli koltuklara yönlendirmektedir. Kişiye özel sinema anlayışı ile bir bakıma evin sunduğu rahatlık, sinema salonlarında taklit edilmekte ve rekabet bu noktada kurulmaktadır.

Sinemaya gitmekten alıkoyan faktörler arasında ulaşım ve zaman bulma sorunları, bilet fiyatlarının bile önüne geçmiş durumdadır. İzleyiciler bu sorunları aştıklarında ise karşılığında teknik yeterlilik ve konfor açısından bu çabayı taçlandıracak bir deneyim talep etmektedirler. Bu ihtiyaçların karşılanması, filme yönelik beklentiler doğrultusunda içeriksel doyumun sağlanmasıyla sonuçlanır.

Çalışmada cevap verilmesi amaçlanan araştırma sorularının ikincisinde; izleyicilerin hangi motivasyonlar doğrultusunda sinema salonlarının dışında film izlemeye yöneldikleri ve sinema içinde ve dişında hangi benzerliklerin ve farklılıkların yaşandığı sorgulanmaktadır. Sinema salonu dışında film izleme pratikleri görüşme yapılan tüm katılımcılar arasında benimsenmiştir. Katılımcılar filmleri en çok ücretsiz platformlar üzerinden tüketmekte; bu sayede yüksek bilet fiyatları ve ulaşım, zaman ve mevsimsel koşullar gibi engelleri aşma yoluna gitmektedirler. Filmlere hızlıca erişim imkanı sunması, bazı filmlerin vizyon tarihinden önce izlenebilmesi ve doğrudan internet üzerinden tüketilmesi önemli kıstaslardır. Bireylerin çeşitli imkanlar doğrultusunda ne olursa olsun tüketme düşüncesini benimsemesi ile platform 
agnostik tanımı geçerlik kazanmaktadır. Abonelik isteyen platformlar genelde ortaklaşa kullanılmaktadır. Reklamsız ve güvenli bir izleme deneyimi yaşama, belirli dönemlerde yenilenen içerikleri makul bir ücret karşılığ1 izleme isteği ücretli platformları cazip kılmaktadır. Katılımcılar sinema salonunun dışında film izleme deneyiminde kullandıkları araç üzerindeki kontrolü vurgulamaktadırlar. Araç üzerindeki kontrol; içeriğin de değiştirilmesini sağlamakta, geciktirimli izleme deneyimine geçiş yapılmaktadır. Parçalanmış bir film izleme deneyimi, içeriğin yönetmen tarafından belirlenmiş devamlılığının ve anlatı yapısının önemsiz hale gelmesine yol açmaktadır. Sinema salonlarındaki seçici izleme deneyimine karşın sinema salonu dışında film izleme deneyiminde izleyiciler içeriğe yönelik beklentilerini azaltmakta; zamandan, mekandan ve ekonomik bağımsızlıktan kaynaklı olarak her türlü içeriği tüketme tercihinde bulunabilmektedirler. Medya ürünlerine fiziksel açıdan sahip olma isteği azalmakta, koleksiyonerlik raflardan dijital depolara taşınmaktadır. Böylece bir filmi sinema salonu dışında izleme deneyiminde kullanım kolaylığı, erişim ve ağlara bağlanma gücü ile süreçsel doyumun karşılandığı söylenebilir.

Önceki çalışmalara göre tespit edilen en önemli farklılık ise sinema salonu dışında sosyal izleyicilik oranının düşük kalmasıdır. Sinema sosyalleşmeye kapı aralayan bir pratik olarak görülürken sinema salonu dışında film izlemek; sosyalleşememe ya da sosyalleşmek istememe düşüncesi ile ilişkilidir. Buna karşın filmlere sinemada vizyona girmeden ulaşma ihtimali; film izleme deneyiminin sonrasında bir tartışma, görüş belirtme ve sosyalleşme imkanı sunmaktadır. Film izlerken ikinci ekranlar ile araştırma yapılabilmesi ya da sohbet edilebilmesi, sinema salonunun dışındaki izleyiciliğin sosyal doyumu farklı bir biçimde sağladığını işaret etmektedir. Film bittikten sonra da yeni iletişim ortamları, sinema deneyiminin devamını bir ölçüde sağlamaktadır. Filmle ilgili oluşan bireysel düşüncelerin doğrulanması ya da farklı fikirler üzerinden beyin jimnastiği yapılması mümkündür.

Sinema salonunda film izleme deneyiminin güncelliğini korumasındaki en önemli faktörler; sosyal ve kolektif bir izleyicilik deneyimi sağlamakla birlikte izleyicilerin kendi deneyimlerini aşan teknik unsurlarla çevrelenmeleridir. Bu güce karşın; sinema salonu dışında film izleme deneyimi de getirdiği kolaylıklar ve sosyal medya araçlarının sunduğu farklı sosyalliklerle entegrasyonu ile etkisini artırmaktadır. İzleyicinin perde karşısındaki gönüllü pasifliği ile medya araçlarının üzerindeki aktif hakimiyeti arasında bir 
deneyim farklılı̆̆1 vardır. Sinema deneyimi tek ve özgün bir deneyim olmaktan çıkmakta, hangi modelin tercih edileceği izleyici bırakılmaktadır.

Çalışmada cevap verilmesi amaçlanan üçüncü araştırma sorusunda izleyicilik deneyiminin geçirdiği değişimler sonucunda film izleme pratiklerinin geleceği sorgulanmaktadır. Sinema deneyiminin parçalanması ve çoğullaşması, izleyicilerin sinema salonunda film izleme davranışlarını da etkilemektedir. İzleyiciler çevrimiçi araçlar aracılı̆̆ıyla film esnasında farklı dünyalara ulaşabilmektedirler. Bu yaklaşım, sinemanın ritüel özelliklerini ön plana çıaran izleyicilerle aralarında bir gerilim doğurmaktadır. Bu nedenle ilerleyen zamanlarda sinema salonlarının bireysel açıdan olduğu kadar farklı kolektif deneyimler sunma açısından da parçalanacağı söylenebilir. Telefonların veya yiyecek-içeceklerin yasak olduğu salonlar ile insanların rahatlıkla hareket edebildikleri salonların ayrışması beklenebilir. Çapraz platformlar arasında kalan izleyicinin içeriğe çeşitli müdahalelerde bulunabileceği çevrimiçi uygulamalar, onun perde ile olan deneyimini de özelleştirecektir.

Türkiye özelinde sinema endüstrisinin yapım, dağıtım ve gösterim alanındaki tekelleşme ve yoğunlaşma gibi büyük sorunları vardır. Az sayıdaki yerli ve yabancı yapımın birçok salonu ve perdeyi işgal etmesi, çok sayıda filmin vizyona ulaşmasını ya da kendisine uzun süreli yer bulmasını engellemektedir. Bu durumda izleyicilerin bir kısmı sinema salonlarına gitmek yerine çevrimiçi platformları ve özellikle yasal olmayan izleme sitelerini tercih etmektedirler. Bu tarz sitelerin sunduğu kalitesiz ve reklamlı izleme deneyimi, film izleme deneyimine yönelik olumlu algıları da değiştirmekte ve ekonomik açıdan da olumsuz bir durum yaratmaktadır. Sinema salonlarının çeşitliliğe yer açmaması ve teknik birtakım sorunları aşamaması durumunda bu sorunun çözülmesi mümkün olamayacaktır.

18 Ocak 2019 tarihinde kabul edilen ve 30 Ocak 2019'da Resmi Gazete'de yayınlanan 7163 sayılı "Sinema Filmlerinin Değerlendirilmesi ve Sınıflandırılması ile Desteklenmesi Hakkında Kanunda Değişiklik Yapılmasına Dair Kanun" ile salonların promosyonlu bilet uygulaması sona ermiştir. Yapımcllar ve multipleksler arasındaki uzlaşmanın olumsuz etkisini ise bağımsız salonlar yaşamaktadır. Örneğin; Beyoğlu Sineması'nın ayakta kalabilmek için başlattığ 1 "Sadakat Kartı" uygulaması, bu kanun nedeniyle sona ermiştir. Bağımsız salonlar gibi alternatif ve çoğunlukla tarihi geçmişi olan film izleme mekanlarının korunamaması, kolektif izleme deneyiminin unutul- 
masına ve bağımsız filmlerin gösterim şansı bulamamasına neden olmaktadır. Salonların tekelleşmesi ve gösterim imkanları açısından vasata ulaşamaması, sinema salonu dişında film izleme deneyimini "yeni normal"e dönüştürmektedir.

2020 yılının Mart ayından itibaren Türkiye' de görülen COVID-19 salgını, sinema endüstrisine ekonomik olduğu kadar kültürel ve sosyal bir darbe de vurmuştur. İzleyicinin sinema salonundan uzun süreli kopuşunun etkisi ve bu bağın nasıl yeniden kurulacağı merak konusudur. Sinemanın sosyal bir kurum olarak film izleme düşüncesini aşan ve toplumsal bir pratiğe dönüşen yapısının bu süreçten olumsuz etkilendiği açık olsa da, yeni teknolojilerin yanı sıra daha önce yaşanan savaşlara ve salgınlara rağmen varlığını koruduğu da unutulmamalıdır.

Bu sorunlar düşünüldüğünde; kültür alanında yapısal reformlar görülmediği sürece sinema salonu dışında film izleme deneyiminin asıl izleme deneyimine dönüşmesi ve sinema salonunda film izleme deneyiminin bir hatıra olarak anılması riski bulunmaktadır. Video platformların tamamen izleyici beğenileri üzerinden proje üretme çabalarl; sinema sanatına yapılacak yaratıcı katkıların görmezden gelinmesine ve şablon ürünlerin ortaya çıkmasına neden olurken, dijital sinemanın yarattığı imkanlar doğrultusunda izleyicilerin oluşturduğu transmedya içerikleri sektörün demokratikleşmesi açısından bir umut doğurmaktadır. 


\title{
EXTENDED ABSTRACT
}

\section{From Silver Screen To Digital Media: A Research on the Change of Film Watching Experience}

\author{
Batu Anadolu \\ Cukurova University
}

As an art form and industry, cinema has been changing in terms of audience participation as well as the production and distribution processes for over a century. The concept of "digital cinema", which has been used since the 1980s, creates a new language beyond technological developments. The traces of this new language can be seen through innovations in traditional exhibition methods. For example; the number of films in Turkish cinema started to increase in parallel with the number of audience and movie theaters in the 21st century. New problems arise in the cinema industry, where multiplexes have become the dominant force with the effect of digitalization and shopping malls. Along with the digitalization of the image and the diversification of exhibition practices, it is possible for the audience to consume a film whenever and wherever they want. Besides, watching pirated or bootlegged films is one of the problems faced by the industry with convergence.

Through cinema, people's cultural lives and their relationships with each other are changing dynamically. Movie theaters, where audiences come together, mark the birth of a public space where films are consumed. Movie theaters is not a designed or designated place. It is a space that is constantly built and structured by the audience. Physical and emotional participation of audience who sees a movie in a theater is an important factor.

Considering that the experience of new technological devices is constantly changing today, the ontology of cinema becomes questionable. Despite the selective watching experience in movie theaters, audiences can choose to consume all kinds of content due to time, space and economic independence outside the theaters. The possibilities created by alternative watching experiences are getting more and more acceptable to the audience.

Purpose of this study is to define the practices and motivations that cause the audience to see movies in the movie theater in the historical process 
and compare them with the factors that lead to watching films outside the movie theater which is widespread on digital media today. For this purpose, a semi-structured questionnaire was prepared and in-depth interviews were conducted with forty-eight students from cinema clubs of six universities in Istanbul. In the light of the findings, the experience of watching a film in or outside the movie theater and the activities before and after this experience were questioned. It was determined that the cinema clubs were places where the film watching experience continued, film materials and digital media platforms were shared, and the participants were required to see movies regularly in movie theaters. Through the qualitative data obtained, the factors affecting the selective watching experience were tried to be defined.

In line with the findings; cognitive, emotional and contextual motivations are effective in the choices of the audience to see a film in the movie theater. Contrary to similar studies, spatial factors are also mentioned. The architectural and technological preferences of movie theater, the quality of the audience and the expectations for the ideal watching experience ensure that seeing a movie in the theater is still perceived as a special event.

Outside the movie theater, audiences prefer channels such as Free VideoOn-Demand, Torrent and Subscription Video-On-Demand. Laptop is the most used tool for watching films. It is determined that the choices of watching films outside the theater is primarily an economical decision. Access to many content through new media platforms provides free and direct experience. SVOD-style platforms are preferred because they offer ad-free and high resolution content for a monthly subscription.

Participants' control over the medium they use is an important element in their experience of watching films outside the movie theater. This control is effective in breaking down the continuity of films and reveals the delayed cinema approach. Contrary to previous studies, the most important difference detected is the low rate of socialization among the audiences. An individual watching experience is preferred. However, an effort to discuss, express opinion and socialize is observed in social media and digital platforms after watching films.

It can be said that in the coming years, movie theaters will be fragmented in terms of providing individual experience as well as collective. This problem will not be solved if movie theaters do not allow for diversity and over- 
come technical problems. Also, The COVID-19 outbreak causes movie theaters to close for a long time. It is seen that digital platforms are trying to fill the gap that has emerged. Unless structural reforms are undertaken in the field of culture, there is a risk that the experience of watching films outside the theater will become one and only.

\section{Kaynakça / References}

Abbate, J. (2017). İnternetin popülerleşmesi. D. Crowley (Der.), İletişim Tarihi: TeknolojiKültür-Toplum içinde (s. 472-479). (Çev. Berkay Ersöz). İstanbul: Siyasal Kitabevi.

Abisel, N. (1995). Popüler sinema ve türler. Ankara: İmge.

Akbulut, H. (2016). Sinemaya gitmek ve seyir: Bir sözlü tarih çalışması. D. Bayrakdar (Der.), Türk Film Araştırmalarnnda Yeni Yönelimler 12: Sinema ve Seyirci içinde(s. 231-252). İstanbul: Bağlam.

Akbulut, H. (2020a, Nisan 12). Online platformlar düşmanlaştrılmadan seyir pratiği çoğullaştırılmalı. 18 Kasım tarihinde http://sineblog.org/ozel-soylesi-prof-drhasan-akbulut-online-platformlari-dusmanlastirmadan-seyir-pratigicogullastirilmali/ adresinden erişildi.

Akbulut, H. (2020b, Mayıs 22). Sinema seyirciliği pandemiyle nasil şekillenecek?. 18 Kasım tarihinde https://www.indyturk.com/node/183216/kultur/sinema-seyirciligipandemiyle-nasil-sekillenecek adresinden erişildi.

Arslan, S. (2015). Sinemasal eğlence. M. Oğuz, M. Akser ve Z. Altundağ (Der.), Türk Film Araşttrmalarnnda Yeni Yönelimler 11: Sinema ve Yeni içinde (s. 203-209). İstanbul: Bağlam.

Atkinson, S. (2014).Beyond the screen: Emerging cinema and engaging audiences. Londra: Bloomsbury.

Austin, B. (1986). Motivations for movie attendance. Communication Quarterly, 34(2), 115-126.

Aziz, A. (2008). Sosyal bilimlerde araştırma yöntemleri ve teknikleri. Ankara: Nobel Akademik Yayıncilik.

Balan, C. (2015). Münevverler harikalar sinemasında: Yirminci yüzyll dönümü İstanbul'unda sinema deneyimleri. M. Oğuz, M. Akser ve Z. Altundağ (Der.), Türk Film Araştrrmalarnda Yeni Yönelimler 11: Sinema ve Yeni içinde (s. 195202). İstanbul: Bağlam.

Bellour, R. (2012). The cinema spectator: A special memory. I. Christie (Der.), Audiences Defining and Researching Screen Entertainment Reception içinde (ss. 206-217). Amsterdam: Amsterdam University Press. 
Casetti, F. (2011). Sinemasal deneyim. (Çev. D. Kırmızı). sinecine, 2(2), 81-93.

Castells, M. (2005). Enformasyon çağı: Ekonomi, toplum ve kültür birinci cilt: Ağ toplumunun yükselişi. (E. Kılıç, Çev.). İstanbul: Bilgi Üniversitesi Yayınları.

Cuaron, A. (Yönetmen). (2018). Roma [Film]. Meksika, ABD: Espectáculos Fílmicos El Coyúl, Pimienta Films, Participant MediA, Esperanto Filmoj.

Culkin, N. (2008). Digital cnema: No country for old entrepreneurs?. Journal of Retail Marketing Management Research, 1(2), 44-58.

Diker, C. (2019). Az daha fazladır: Dijital seyir platformlarının tüketim kültürü açısından izleyicilerin seyir alışkanlıklarına olan etkisi. Erciyes İletişim Deroisi, 1, 120.

Erdoğan, Y. (Yönetmen). (2019). Organize İşler: Sazan Sarmalı [Film]. Türkiye: BKM Film.

Erkılıç, H. (2009). Düş şatolarından çoklu salonlara değişen seyir kültürü ve sinema. Kebikeç Dergisi, 27, 143-162.

Erkılıç, H. (2020, Mayıs 1). Dijital platformlarm yükselişini dillendirmek sinemaya ihanet değil. [Blog yazısı]18 Kasım tarihinde http://sineblog.org/ozel-soylesi-doc-drhakan-erkilic-dijital-platformlarin-yukselisini-dillendirmek-sinemaya-ihanetdegil/ adresinden erişildi.

Göker, N. (2017).Türkiye' de sinema seyircisi: İstanbul, Ankara ve İzmir örneğinde bir izleyici araşturması. The Journal Of Academic Social Science Studies, 64, 431-456.

Göker, N. (2018). Sinema seyirci ilişkisini etki çerçevesinde düşünmek bir izleyici araştırmasının sonuçları. Akdeniz Üniversitesi İletişim Fakültesi Dergisi, 29, 270-292.

Habermas, J. (2004). Kamusal alan (M. Özbek, Der.), Kamusal Alan içinde (s. 95-102). (M. Özbek, Çev.). İstanbul: Hil Yayın.

Hall, S. (2001). Encoding, decoding. S. During (Der.), The Cultural Studies Reader içinde (s. 507-517). Londra: Routledge.

Hansen, M. (1991). Babel E Babylon: Spectatorship in American silent film. Massachusetts: Harvard University Press.

Hansen, M. (2004). Yirmi yılın ardından Negt ve Kluge'nin "kamusal alan ve tecrübe"si: Değişken karışımlar ve genişlemiş alanlar. (M. Özbek, Der.), Kamusal Alan içinde (s. 141-177). (M. Özbek, Çev.). İstanbul: Hil Yayın.

Hansen, M. (2012). Cinema and experience. Los Angeles: University of California Press.

Hilmes, M. (2009). Digital television: High definitions. (G. Creeber ve R. Martin, Der.), Digital Cultures içinde (s. 46-60). Berkshire: Open University Press-McGrawHill.

Jarvie, I.C. (2013). Towards a sociology of the cinema: A comparative essay on the structure and functioning of a major entertainment industry. Londra: Routledge. 
Jenkins, H. (2006). Convergence Culture: Where Old and New Media Collide. New York: New York University Press.

Jensen, K.B. (2005). Danimarka televizyon haberleri hakkında nitel ampirik bir çalışma. Ş. Yavuz (Der.), Medya ve İzleyici: Bitmeyen Tartışma içinde (s. 131-159). (Ş. Yavuz, Çev.). Ankara: Vadi Yayınları.

Kanzler, M. (2014).The Turkish film industry: Key developments 2004 to 2013. Strasbourg, European Audiovisual Observatory.

Karaduman, S. (2018). Yeni iletişim teknolojileri ve film izleme alışkanlıkları. Akdeniz Üniversitesi Sosyal Bilimler Enstitüsü Dergisi, 1(2), 163-174.

Katıksız, A. ve Yorulmazer, D. (Yönetmen). (2020). Aşk 101 [Dizi]. Türkiye: Ay Yapım.

Katz, E. ve Foulkes, D. (1962). On the use of the mass media as escape: Clarification of a concept. Public Opinion Quarterly, 26, 377-388.

Kırel, S. (2012). Kültürel Çalışmalar ve sinema. İstanbul: Kırmızı Kedi Yayınları.

Kim, H., S. Park ve Park, Y. (2014).Study on satisfaction of movie viewers watching movies on smartphones. Advanced Science and Technology Letters, 67, 78-83.

Konukman, E. (2018). Değişen film izleme alışkanlıkları ve sinemada Hollywood gerçeği: Radyo televizyon ve sinema bölümü öğrencilerinin konuya yaklaŞımı. TRT Akademi, 3(5), 304-321.

Lam, C. (2011). Portable media affected spectatorship. Convergence: The International Journal of Research into New Media Technologies, 17(4), 431-443.

Lichtenstein, A. ve Rosenfeld, L.B. (1983). $\quad$ Uses and misuses of gratifications research: An explication of media functions. Communication Research, 10, 97-109.

Liyin, Y. (2020, Temmuz 8). Streaming services sales up 50 percent during the COVID-19 era. $18 \mathrm{Kasim}$ tarihinde https://secondmeasure.com/datapoints/streamingservices-grow-fifty-percent-covid-19/ adresinden erişildi.

Lowe, M. (2020, Ekim 22). Mitch Lowe - Netflix pioneer on the entertainment industry's future and 'Pitch Up In The Sky'. 18 Kasim tarihinde https://www.euronews.com/2020/10/22/mitch-lowe-netflix-pioneer-on-theentertainment-industry-s-future-and-pitch-up-in-the-sky adresinden erişildi.

Maxwell, R. ve Miller, T. (2011). Old, new and middle-aged media convergence. Cultural Studies, 25(4), 585603.

Mayne, J. (1993). Cinema and spectatorship. Londra: Routledge.

McQuail, D. (2005). McQuail's mass communication theory. Londra: Sage.

McQuail, D. ve Windahl, S. (2010).Iletişim modelleri - Kitle iletişim çalışmalarnda. (K. Yumlu, Çev.). Ankara: İmge.

Medin, B. (2018). Dijital kültür, dijital yerliler ve günümüzdeki yeni film seyir deneyimleri. Erciyes İletişim Dergisi, 5(3), 142-158. 
Medin, B. (2018). Günümüz sinema seyir gündeminin belirlenmesi. Galatasaray Üniversitesi İletişim Dergisi, 28, 43-62.

Mendelsohn, H. (1966). Mass entertainment. New Haven: New Haven College \& University Press.

Mulvey, L. (2012). Saniyede 24 kare ölüm: Dură̆anlık ve hareketli görüntü. (S. Dingiloğlu, Çev.). İstanbul: Doruk.

Negt, O. ve Kluge, A. (2004). Kamusal alan ve tecrübe'ye giriş. (M. Özbek, Der.), Kamusal Alan içinde (s. 133-139). (M. Özbek, Çev). İstanbul: Hil Yayın.

Öz, P. (2012). Pelikülden dijitale sinemada seyir kültürü ve seyircinin değişen konumu. The Turkish Online Journal of Design Art and Communication, 2(2), 65-73.

Özen, E. ve Çelenk, S. (2006). Sinema endüstrisinin ekonomik yöndeşme eğilimleri: Hollywood örneği. İletişim: Araştırmalan Dergisi, 4(1), 67-96.

Özsoy, A . (2017). Sinema, yeni seyir deneyimleri ve çocuk izleyici. TRT Akademi, 2(4), 356-374.

Öztürk, F. (2019, Ağustos 2). Netflix: RTÜK'ün internet yönetmeliği ne getiriyor, kurul üyeleri ne diyor?. 18 Eylül 2020 tarihinde https://www.bbc.com/turkce/haberler-turkiye-49193378 adresinden erişildi.

Palmgreen, P., Cook, P. L., Harvill, J. G. ve Helm, D. M. (1988). The motivational framework of moviegoing: Uses and avoidances of theatrical films. Current Research in Film: Audiences, Economics, and Law, 4, 1-23.

Patton, M.Q. (1990).Qualitative evaluation and research methods. Los Angeles: Sage.

Pool, I.S. (1983). Technologies of freedom. Massachusetts: The Belknap Press of Harvard University.

Ravazzoli, E. (2016).Cinemagoing as spatially contextualised cultural and social practice. Alphaville Journal of Film and Screen Media, 11, 33 -44.

Stacey, J. (1994). Star gazing: Hollywood cinema and female spectatorship. Oxford: Routledge.

Stafford, T. F., Stafford M. R. ve Schkade, L. L. (2004). Determining uses and gratifications for the internet. Decision Sciences, 35(2), 259-288.

Staiger, J. (2000). Perverse spectators: The practices of film reception. New York: New York University Press.

Süalp, Z.T. (2004). Kamusal Alan, Deneyim ve Kluge. (Der. M. Özbek), Kamusal Alan içinde (s. 653-675). İstanbul: Hil Yayın.

Tanriöver, H.U. (2011). Türkiye'de film endüstrisinin konumu ve hedefleri. İstanbul: İstanbul Ticaret Odası Yayınları.

Tekin, H.H. (2006). Nitel araştırma yönteminin bir veri toplama tekniği olarak derinlemesine görüşme. İstanbul Üniversitesi Sosyoloji Dergisi, 3(13), 101-116. 
Tryon, C. (2009). Reinventing cinema: Movies in the age of media convergence. New Jersey: Rutgers University Press.

TÜİK. (2020, Haziran 16). Sinema ve tiyatro istatistikleri, 2019. Türkiye İstatistik Kurumu Haber Bülteni. $\quad 18 \quad$ Eylül $2020 \quad$ tarihinde http://www.tuik.gov.tr/PreHaberBultenleri.do?id=33622 adresinden erişildi.

Tüzün, S. (2013). Multipleks sinema salonları ve Türkiye örneğinde sinema sektöründe değişen güç dengeleri. sinecine, 4(1), 85-115.

Ulin, J. (2010). The business of media distribution: Monetizing film, tv and video content in an online world. Massachusetts: Focal Press.

Ünal sansürü doğruladı: Aşk 101'deki Osman eşcinseldi. (2020, Temmuz 7). Gazete $\begin{array}{lllll}\text { Duvar. } & 18 & \text { Eylül } & 2020 & \text { tarihinde }\end{array}$ https://www.gazeteduvar.com.tr/gundem/2020/07/07/unal-sansurudogruladi-ask-101deki-osman-escinseldi/ adresinden erişildi.

Yavuz, D. (2012). Türkiye sinemasınn 22 Yilı: 1990-2011 Sayısal verilerle 22 yıllık döneme bakış. İstanbul: Antrakt Yayınları.

Yavuz, Ş. (2015). Kitle iletişim araştırmalarında anadamar/çoğulcu ve eleştirel/radikal kuram arasında yöndeşme tartışmaları. Karadeniz Teknik Üniversitesi İetişim Araştırmalan Dergisi, 5(1), 25-39.

Yaylagül, L. (2014). Kitle iletişim kuramları: Egemen ve eleştirel yaklaşımlar. Ankara: Dipnot Yayınları.

\section{Kaynakça Bilgisi / Citation Information}

Anadolu, B. (2020). Beyazperdeden dijital medyaya: Film izleme deneyiminin değişimi üzerine bir araştırma. OPUS-Uluslararası Toplum Araştırmaları Dergisi, 16(32), 5075-5110. DOI: 10.26466/opus.796968 